\title{
Essay
}

\section{Taking Out the Adversary: The Assault on Progressive Public-Interest Lawyers}

\author{
David Luban†
}

\section{INTRODUCTION}

This Essay concerns laws and doctrines, some very recent, that undermine the capacity of progressive public-interest lawyers to bring cases. It asks a simple-sounding question: how just is the adversary system if one side is not adequately rcpresented in it? And it defends a simple-sounding answer: It is not just at all. As we shall see, however, neither the question nor the answer is quite as simple as it sounds.

Like most issues implicating distributive justice, the question of who has access to lawyers and who does not has become a political football. Political partisans do not care about impartial justice. They care about rewarding their friends and defeating their enemies, and that means ensuring that their enemies receive as little money as possible, including money to pay for legal advocacy. Advocacy, after all, might be used to turn the tables. In the last few years, a disturbing pattern of legal attacks on publicinterest lawyers has emerged, targeting every one of the principal sources of support for progressive public-interest law: the Legal Services Corporation ("LSC"), state Interest on Lawyers Trust Account ("IOLTA")

Copyright $\bigcirc 2003$ California Law Review, Inc. California Law Review, Inc. (CLR) is a California nonprofit corporation. CLR and the authors are solely responsible for the content of their publications.

$\dagger \quad$ Frederick Haas Professor of Law and Philosophy, Georgetown University Law Center. This Essay was originally delivered as the Irving S. Ribicoff Memorial Lecture at Yale Law School, October 30, 2001, and again at Yale in March, 2002, as the keynote address at the Arthur Liman Colloquium. I presented a much longer and rougher version at the Columbia Legal Theory Workshop and the Georgetown Faculty Research Workshop, and discussed the Essay at the Brennan Center. 1 am most grateful for the many helpful comments 1 received from all these audiences. A much-abbreviated version appeared as David Luban, Silence! How the Courts and Congress Silence Poor Peoples' Lawyers, 1 LEGAL AFF. 54 (May/June 2002). For in-depth help in the form of comments, conversation, and information, I would like to thank four Davids: David Chavkin, David Hyman, David Udell, and David Vladeck. Peter Joy and Adam Babich helped me with information about the Tulane clinic affair, as did my colleagues Hope Babcock and John Copacino. 
programs, law school clinics, and civil rights attorney's fees. ${ }^{1}$ The attacks seek to win political disputes not by offering better arguments, but by defunding or otherwise hobbling the advocates who make the arguments for the other side. Suitable analogies might be found in a story about Lyndon Johnson defeating insurgents in the Texas Democratic Party by arranging to have the microphone unplugged when they got up to speak at the party convention, ${ }^{2}$ or Republican consultant Ed Rollins's boast (which he later

1. I suspect most readers understand adequately what the phrase "progressive public-intcrest law" means, but it may neverthelcss be worth discussing the terminology briefly. By "public-interest law," I do not mean "law practiced on behalf of the public interest." That usage would make the phrase completely tendentious, because people disagree fundamentally over what the public interest is. Those on opposite ends of the political spectrum are likely to insist that they are practicing law in the public interest but their counterparts on the other side are not. I think that onc should instead look for less loaded criteria. As I use the term, a public-interest lawyer is a lawyer for whom making money is not the primary purpose for taking a case-or, to put it in different tcrms, a lawyer who would like to take the case pro bono if it were feasible to do so. This minimalist definition aims to capture common-sense usage. An additional criterion, different from and not always consistent with the minimalist one, is that public-interest lawyers represent interests that would not otherwise be represented in the legal system. Though different, the two eriteria are connected, because most lawyers would not take on pro bono cases from clients who can afford paid counsel, even if it were economically feasiblc to do so. Thus, cases that meet the first criterion (the lawyer would like to take the case pro bono) will typically meet the second criterion as well (the client would not otherwise be represented in the legal system). These criteria, rough as they are, avoid begging political questions. They include public interest law on the right as well as the left, and they include lawyers delivering routine legal services to low incomc clients-my principal focus in this Essay-as well as lawyers representing causes. The second criterion does rule out self-styled "public interest" organizations that are rcally front groups for well-funded corporate interests that think it bad public relations to operate under their own flag. Some might see this structurc as an anticonservative bias built into the definition. But I think not: calling front groups for well-represented parties "public-interest lawyers" simply eliminates the basic functional difference bctween public-intcrest lawyers and lawyers for paying clients.

My use of the word "progressive" is also minimal and close to what has become common usage. Over time, the word has lost its connection with its root, "progress," just as its antonym, "conservative," no longer possesses much connection with "conserve." Just as today "conservative" means little more than right-of-center, "progressive" means left-of-eenter, or, more specifically, something like "socially and economically egalitarian in domestie affairs, and cosmopolitan in international affairs." It is not easy to characterize progressives politically: in some instances, they are statists who favor government regulation, while in others they oppose the state. Likewise, in some cases they strongly favor democracies, while in others thcy uphold minority rights against the will of majoritics.

A natural question arising from these definitions is what makcs legal services for low-income clients "progressive"? After all, many lawyers who would never consider themselves left-of-center take on pro bono cases; and many pro bono cases have nothing to do with cgalitarian or cosmopolitan causcs. They have to do with relatively apolitical legal issues, such as helping poor people navigate hidebound municipal burcaucracies. One simple answer to the question of why low-ineome legal services are progressive is, quite simply, that providing costly services to low-income clients for free is in itself egalitarian. A more subtle answer is that poor people move in a legal landscape dominated by public bureaucracies, absentee slumlords, ruthless creditors, policing at its nastiest, incarcerated breadwinners, and consumer rip-offs. More abstractly, they move in a legal landscape in which rulcs are designed less to protect them than to protect nonpoor society against people like them. For that reason, even routinc advocacy for poor clients often requires working against the grain of the law as it stands, to the discomfiture of the powerful.

2. I recall reading this anecdote about Johnson some years ago, but I have been unable to locate the source. Any reader so inclined may treat the story as apocryphal. 
recanted) that he had paid Black ministers to sit on their hands rather than telling their flocks to vote in the 1992 New Jersey gubernatorial race. ${ }^{3}$ Just as tactics like these are dirty politics, this Essay argues that taking out your adversary's lawyers is dirty law.

To understand the issues properly, some background on what is sometimes called the "access to justice" problem in the United States is helpful. Law is a $\$ 100$ billion per year industry. ${ }^{4}$ Of that $\$ 100$ billion, however, less than $\$ 1$ billion is dedicated to delivering legal services to low-income Americans. ${ }^{5}$ Put in terms of people rather than dollars, there is about one lawyer for every 240 nonpoor Americans, but only one lawyer for every 9,000 Americans whose low income would qualify them for legal aid. ${ }^{6}$ Forty-five million Americans qualify for civil legal aid, ${ }^{7}$ and they are served by a mere 4,000 legal-aid lawyers plus an estimated 1,000 to 2,000 additional poor people's lawyers. ${ }^{8}$ Although the myth persists that the very

3. See Jerry Gray, Rollins Says He Fabricated Payoff Tale to Irk Foes, N.Y. Times, Nov. 20, 1993, at Al.

4. Statistical Abstract of the United States: 1999, No. 1270 (U.S. Census Bureau 2000), available at http://www.census.gov/prod/99pubs/99statab/sec27.pdf.

5. The $\$ 1$ billion figure may overestimate the amount given to support low-income Americans. 1 arrived at this figurc by adding together all the major providers of such services. The LSC provides $\$ 330$ million, of which $\$ 310$ million is dedicated to client representation. See LSC website, at http://www.lsc.gov/press/02a.htm. According to the American Bar Association's Project to Expand Resourees for Legal Services ("PERLS"), statc IOLTA programs provided an additional \$125 million in 2001. PERLS reports that in 2001, legal services obtained $\$ 363,979,400$ from the following sources: court fees and fines $(\$ 36,799,000)$; state appropriations $(\$ 66,436,000)$; other non-LSC public funds $(\$ 135,175,500)$; lawycr fund drives $(\$ 22,225,000)$; attorney-registration fees $(\$ 1,441,000)$; bar funds $(\$ 9,401,700)$; bar dues add-ons and check-offs $(\$ 772,000)$; cy pres funds $(\$ 1,297,500)$; foundation and corporate grants $(\$ 39,314,200)$; and miscellaneous contributions (mostly United Way and Skadden and NAPIL fellowships) $(\$ 51,118,000)$. See PERLS: A Chart of Significant Fundraising Activities for Legal Services, at http:/www.abanet.org/legalservices/sclaid/sclaid_body.html (last visited Oct. 5, 2002) [hereinafter PERLS]. The computations are my own, based on data provided on this wcbsitc. The total is roughly $\$ 800$ million.

6. This estimatc refcrs to civil, not criminal, lawyers.

7. In $1999,32,258,000$ out of a total population of $273,493,000$ Americans lived beneath the poverty line. See U.S. Census Burcau: Poverty 1999, avalable at http://www.census.gov/hhes/ poverty/poverty99/pv99estl.html (last modified Aug. 22, 2002). However, the cutoff for representation by a legal-services lawyer is set at $125 \%$ of the poverty linc, and this brings the eligible-client pool to an estimated 44.5 million. See Legal Servs. Corp., Serving the Legal Nefid of Low-lncome Americans 13 (Apr. 2000), at http://www.lsc.gov/pressr/EXSUM.pdf. According to the February 23, 2002 testimony of the LSC president bcfore the Committee of the Judiciary, the number of people that can be served by the LSC is forty-three million. See John Erlenborn, Statement of the Legal Services Corporation (Fcb. 23, 2002), available at http://www.lsc.gov/pressr/pr_test.htm. The current economic downturn is very likely to have boosted the number, perhaps to the fifty million that then-LSC President Alexander D. Forger estimated in 1994. See James Podgers, Chasing the Ideal, 80 A.B.A.J. 56, 57 (Aug. 1994).

8. There are no wholly reliable estimates of the number of public-intercst civil lawyers in the United States. Informed sources put the number between 5,000 and 6,000; that is, 4,000 LSC-funded lawyers plus between 1,000 and 2,000 non-LSC recipients. Marc Galanter extrapolates from older figures and places the number at 6,000. See Marc Galanter, "Old and in the Way": The Coming Demographic Transformation of the Legal Profession and Its Implications for the Provision of Legal Services, 1999 WIS. L. REv. 1081 , 1103 n.55 (1999). David Vladeck, however, believes that Galanter's 
rich and the very poor have no trouble getting lawyers (because the rich have money and the poor qualify for legal aid), and that only the middle class is squeezed, these numbers reveal the true scarcity of lawyers and services available to low-income people. In very real effect, low-income Americans are denied access to justice. ${ }^{9}$ The reason is simple: one lawyer

assumption that the public-interest bar has grown proportionately to the bar as a whole is excessively optimistic. See David C. Vladeck, Hard Choices: Thoughts for New Lawyers, 10 KAN. J.L. \& PuB. PoL'y 351, 352 n.7 (2001). 1 am inclined to agree with Vladeck, if for no other reason than that the fraction of the total national expenditure on legal services devoted to poor people's lawyers decreased $50 \%$ between 1982 and 1997. See Galanter, supra, at 1104 . 1t seems unlikely that this phenomenon has permitted the public-interest sector of the bar to grow as rapidly as the rest. In addition to legal-services lawyers, there are a few hundred public-interest lawyers working for causes across the political spectrum, from gay rights to the rights of Christian home-school students, from consumer protection to business deregulation, from nailing the $\mathrm{Ku}$ Klux Klan to nailing Bill Clinton.

9. Critics will argue that access to justice is a concept with no real meaning because the level of access to lawycrs that justice requires is impossible to specify. Does access mean every nonfrivolous litigable case should have a lawyer funded by the government? Such a notion raises two problems. First, it implies a higher level of access than even the wealthiest purchasers of legal serviees enjoy. Even wealthy clients have limited budgets and must pick and choose which cases to litigate. Second, the concept of a "litigable case" is inherently indeterminate. The point at which a dispute breaks through from the informal to the formal legal system depends in part on the cost of legal services; no dispute is intrinsically litigable or not. If lawyers were cost-free, then perhaps even extremely trivial disputes would migrate into the formal system. This hardly seems like a desirable state of affairs. Increasing the supply of free lawyers would undoubtedly drive up demand, so "access to justice" becomes a receding target.

Perhaps "access" ideally entails that every cost-beneficial case should have a lawyer. Here, too, the eoneept is indeterminate: whether a case is cost beneficial depends on how expensive a lawyer is. Maybe a better approach is that every case that would be cost beneficial for a litigant to bring if the lawyer were charging normal market rates should have a lawyer. But this neglects the possibility that although the litigation is cost beneficial to the plaintiff, the total social costs of providing formal justice outwcigh the benefit. Alternatively, access to justiee could be defined in terms of access for any matter that concerns a significant interest of the litigant. This, however, seems too restrictive: surely, poor people should be able to use the formal system to redress grievances even if they do not involve major rights violations.

The definitional questions become even more vexing once we realize that lawyers can be useful for many law-related problems that do not involve litigation. A great many poor person's problems can be solved by a legally knowledgeable, articulate person making a few phone calls. But if the criterion of access means that everyone can obtain legal services whenever the services would be useful, we confront the fact that a good lawyer is an extremely useful person: a good lawyer is shrewd, adept at navigating the waters of institutional life, and prudent. Most of us could use one almost all the time, and this ideal of full access raises the nightmarish vision of everyone with their own personal general counsel accompanying them through daily life.

The conclusion of these arguments is that the ideal of access to justice-embodied most famously in the motto "Equal Justice Under Law" emblazoned on the Supreme Court building-threatens to land us on unacceptable slippery slopes under even the most plausible interpretations. But it is possible to cut those Gordian knots. Even if precise specification of equal justice under law eludes us, we know what equal justice is not. Creating legal institutions that can be navigated only by people with lawyers violates any meaningful interpretation of "equal justice under law" if large segments of the population cannot obtain a lawyer. Because lawyers are expcnsive, market-based distribution of legal services would exclude at least forty million people from aecess to legal institutions, and it follows that marketbased distribution of legal services violates the equal-access ideal. See David LUBAN, LAWYERS AND JUSTICE: AN ETHICAL STUDY 243-66 (1988). Our current system of subsidized legal services for the poor, however, is nearly indistinguishable from market-based distribution: it leaves 95 percent of poor people's lcgal needs unaddressed. See infra note 10 and accompanying text. Whatever the definition of 
per 9,000 clients. To put in perspective what those numbers mean, the American Bar Association's Comprehensive Legal Needs Study found that every year about half of low-income people face legal needs-that is, "situations, events, or difficulties any member of the household faced . . . that raised legal issues."10 That amounts to 4,500 cases a year for each lawyer-90 a week, 18 a day. Obviously, no lawyer can handle a caseload that large. Even supposing that a lawyer could handle one case a day-itself an incredible assumption-the result would be that $95 \%$ of low-income people's legal needs remain unaddressed.

The central fact, then, is the egregious scarcity of public-interest lawyers. Five thousand lawyers for 45 million clients-one lawyer per 9,000 low-income people. That is the problem of access to justice. Although many readers will feel intuitively that targeting the already minuscule population of public-interest lawyers is wrong, the first Part of this Essay will set out a philosophical lens through which to view the problem. 1 argue that "taking out the adversary"--targeting advocates for the other side rather than arguing against them on the merits--robs the adversary system of its strongest claim to legitimacy. The second Part of this Essay turns to examples of targeting progressive public-interest lawyers by attacking the LSC, state 1OLTA programs, law school clinics, and civil rights attorneys' fees.

Audi Alteram Partem and the Adversary System

In his recent book Justice Is Conflict, the distinguished philosopher Stuart Hampshire sets out an argument that conflict is a component of justice, not an obstacle to achieving it. "Hampshire's starting point is the familiar Platonic idea that justice within the city mirrors justice within the soul. For Plato, justice in both the city and the soul consists of harmonizing conflicting desires under the supervision of reason. ${ }^{12}$ Hampshire proposes to turn this Platonic picture upside down. While Hampshire agrees that the soul and society mirror one another, he rejects both the supremacy of reason and the demand for harmony. Instead, he insists that conflict is "unavoidable and desirable" in both society and the soul. ${ }^{13}$ According to

access to justice turns out to be, we are nowhere near it. And so any cutback or restriction in legal services from the little we do now represents a stcp in the wrong direction.

10. Am. Bar Assoc., Legal Needs and Civil Justice: A Survey of Americans, Major Findings from the Comprehensive Legal Needs Study 2 (1994).

11. See Stuart Hampshire, Justice Is Conflict 37 (2000).

12. Plato, The Republic *368c-369a (analogizing justicc within the city to justice within the soul); id. at $* 434 \mathrm{~d}-441 \mathrm{e}$ (arguing that both city and soul are divided into three parts: the rational, the spirited, and the desiring; and that justice requires the rational part to rule the other two parts); $i d$. at * $443 \mathrm{c}$-e (concluding that justice consists of harmonizing the three parts of the soul, like three musical notes in a chord).

13. HAMPSHIRE, supra note 11 , at 37 . 
Hampshire, human values arise not from the intellect (in which case everyone's values might converge) but from memory and imagination. These are primordial forces, and they are idiosyncratic to the core. ${ }^{14}$

As a result, conceptions of the good are irreducibly diverse, and ideals are "polymorphous." ${ }^{15}$ Conflict flows from human plurality, and ultimately from human imagination. We might say that conflict is imagination's trace in the world. Human plurality implies the hopelessness of the philosophical quest to deduce some mastcr principle of substantive justice. All such deductions are circular, because people will never agree on starting points. In place of substantive justice, Hampshire therefore offers a principle of bareminimum procedural justice, "the single prescription audi alteram partem ("hear the other side')." ${ }^{\text {"16 }}$ Hampshire titles this maxim the "principle of adversary argument," 17 and the label is an apt one. The common-law maxim audi alteram partem has long been recognized as a fundamental principle of adversary adjudication, reflecting the common lawyer's deep suspicion of ex parte decision making. The maxim originated as a principle forbidding criminal conviction without hearing a defense-Black's Law Dictionary paraphrases it "[n]o one should be condemned unheard"18_but today it has broadened beyond criminal law. As Justice Frankfurter wrote,

Audi alteram partem-hear the other side!-a demand made insistently through the centuries, is now a command, spoken with the voice of the Due Process Clause of the Fourteenth Amendment, against state governments, and every branch of them-executive, legislative, and judicial - whenever any individual, however lowly and unfortunate, asserts a legal claim. ${ }^{19}$

14. Hampshire argues for these views in detail in HAMPSHIRE, INNOCENCE AND EXPERIENCE 113 34 (1989). According to Hampshire, "[t]he essence of humanity, in the sense of the principal salient distinguishing characteristic, is precisely a perpetual openness to new ways of life, to new forms of thought, to innovations in language and in social arrangements." Id. at 30 . This capacity is what he means by imagination. His basic argument about memory is this:

The peculiar intensity of learning to speak and to understand one's native language, and of a very prolonged upbringing and dependency in a family, and the rituals attached to phases of maturity, all together establish an identity and a pattern. A person's intentions for the future conduct of her life often seem to her to be a development of the desircs and aims which she can trace back to influences in her childhood, making sense of a long tract of time: as if she can see herself passing from preparation to a possession of powers and habits which at first she did not know that she could possess.

Id. at 147. Hampshire reminds us how much of our inner life, the crucible in which our values are formed, consists of fantasizing and reminiscing-imagination and memory. For most of us, 1 suspect, fantasizing and reminiscing take up nearly all our waking life when we are not engaged in practical activity. Hampshire's second point is that both fantasizing and reminiscing are strongly individual. Id. at 114-15, 125-28. No two people's fantasies and memories are the same. The irreducible individuality of these two basic value-forming mental activities is the source of moral diversity.

15. HAMPSHIRE, supra note 11 , at 52 .

16. Id. at 8 .

17. Id. at 8-9.

18. Black's Law Dictionary 1620 (7th ed. 1999).

19. Caritativo v. California, 357 U.S. 549, 558 (1958) (Frankfurter, J., dissenting). 
Properly understood, the principle of adversary argument requires more than merely letting the other side say its piece before a closed-minded tribunal that has already prejudged the matter. Even show trials do that. Audi alteram partem requires actually listening to the other side in good faith, even when the chance of changing the decision maker's mind is virtually nil. Hearing the other side in good faith requircs setting one's prejudices aside, and that makes it a powerful, hard-to-live-up-to moral requirement, even though it is "merely" procedural.

Hampshire aims to broaden the maxim's scope beyond law to politics, and even to the inner deliberative process by which we make personal choices. The reason lies in his insights that the principle of adversary argument gives proper scope to conflict, and that conflict is at once the source and the consequence of pluralism. The Platonic ideal of reason subordinating unruly impulses to a single principle must be abandoned because the world itself answers to Heraclitus's vision of eternal cosmic conflict, not Plato's vision of an underlying reasoned harmony. All of nature consists of "different units, struggling, wittingly or unwittingly, to preserve their individual character and their distinctive qualities against the encroachment and absorption of other sclf-assertive things in their environment." ${ }^{20}$ Though Hampshire acknowledges that "[t]his is a metaphysical vision, a speculation," it underlies his picture of everlasting conflict in the soul and in society, a conflict that can never be eliminated, only managed and made tolerable by practices of adversarial argument embodied in fair procedures. ${ }^{21}$ Even individual rationality consists not in "formal deductions and proofs," but rather "the habit of balanced adversary thinking," that is, "mental processes which are modeled on the public procedures." 22 Faced, as we inevitably are, with choices among incompatible possibilities that are valuable in different ways, choosing wisely requires us to explore in our imaginations the claim each possibility makes on us. That means welcoming a certain amount of inner turmoil. Only the fanatic rejects alternatives without considering them. Fanatics avoid inner turmoil, but they do it by avoiding inner give and take, the basic form of practical reasoning. Hampshire's conclusion is a striking one: "We are citizens who have a feeling for justice in public affairs because we have faction-ridden souls torn between contrary impulses, and we are persons who are normally in dispute with ourselves." ${ }^{23}$ The experience of inner dispute is really where our feeling for procedural justice comes from. Hearing the other side is as basic to practical reason as counting is to arithmetic.

20. HAMPSHIRE, supra note 11 , at 38-39.

21. Id. at 39.

22. Id. at 14,9 .

23. Id. at 72 . 
Hampshire's thesis seems to me a bolder one than John Rawls's emphasis on "the fact of pluralism," which both Rawls and Hampshire recognize as fundamental to human life. ${ }^{24}$ To say that pluralism is a fact is not to say that it is a desirable fact (after all, death too is a fact), and to anyone who believes that moral and religious questions have one demonstrable right answer, the fact of pluralism will seem like a regrettable reality that one must work around. It would be better if all men and women accepted the truth, although that will never happen. We settle for cacophony, but we would prefer monophony. This view (I do not assert that Rawls holds it) ${ }^{25}$ seems fully consistent with the Platonie identification of the Good and the True.

Hampshire's point is more radical. To say that justice is conflict implies that conflict and pluralism are preferable to unanimity, because unanimity could be obtained only by suppressing or impoverishing memory and imagination. On this view, pluralism is a human good as well as a brute fact. If indeed pluralism follows from the individuality and idiosyncrasy of memory and imagination, and if indeed memory and imagination are fundamental human goods, then conflict and cacophony, within and outside us, are more desirable than their absence. And to the extent that

24. John Rawls, The Idea of an Overlapping Consensus, in Collected PAPers 424-25 (Samuel Freeman ed., 1999). For Rawls, the fact of pluralism arises from people's belief in different "comprehensive doctrines," Rawls's term for overall world views such as religions and philosophies. John Rawls, The Domain of the Political and Overlapping Consensus, in COLlected PAPERS, supra, at 480-81. Rawls's use of the word "doctrine" is significant. A doctrine is a set of propositions, a credal theory, a claim of the intellect. As such, the plurality of doctrines can seem like a failure of human rationality. After all, if doctrines are inconsistent with one another, all but the true one are believed wrongly. John Rawls, Pol.ticical Liberalism 129 (1993) [hereinafter Rawls, Political LIBERALISM]. If Hampshire is right that values arise from the idiosyncratic powers of memory and imagination, then it need not be the case that all doctrines or ereeds but one are false.

25. Rawls himself denies that there is only one reasonable doetrine. See Rawls, Political Liberalism, supra note 24, at 58; John Rawls, The Idea of Public Reason Revisited, in Collected PAPERS, supra note 24, at 573. However, that is because he assigns a specialized meaning to "reasonable." In Rawls's philosophy, to call a doctrinc "reasonable" is very different from calling it "truc." See Rawls, Political Liberalism, supra note 24, at xx, 94, 116; John Rawls, Kantian Constructivism in Moral Theory, in Collected PAPERs, supra note 24, at 355 [hereinafter Rawls, Kantian Constructivism l. To call a doctrine "reasonable" means that it can form the basis for fair cooperation among people, not that its truth claims can bc defended by reasons. See Rawls, Kantian Constructivism, supra, at 316. Rawls wishes to focus on the reasonableness rather than the truth of doctrines because to rest politics on claims to truth will be politically divisive. See Rawls, Political Liberalism, supra note 24 , at 129 . However, to call comprehensive value-systems "doctrines" as Rawls does makes it difficult to avoid the question of truth and falsity, as Rawls backhandedly concedes when he acknowledges that reasonable eomprehensive doctrines are partly exercises in theoretical reason. See id. at 59. In this respect, Hampshire's grounding of value systems in memory and imagination rather than in doctrine avoids the worry that pluralism results only from a failure of human rationality. Rawls, too, understands that pluralism results because "the way we assess evidence and weigh moral and political values is shaped by our total experience, our whole course of life up to now; and our total experiences must always differ." Id at 56-57. For Rawls, however, this faet counts as one of the "burdens of judgment." Id at 55-56. The choice of terminology is significant: where Hampshire finds value in idiosyncracy, Rawls finds a "burden." Id. 
adversarial institutions offer venues to voices, while at the same time cabining conflict to a tolerable level, they are good institutions.

Let me summarize the basic point of Hampshire's argument. Conflict should never be eliminated, because the only way to eliminate conflict is by eliminating human plurality, human memory, and human imagination. To eliminate conflict is to impoverish the human world. Obviously, this is not an argument against resolving conflicts. On the contrary, it is an argument against repressing or denying conflicts without resolving them, perhaps by coercing one side into dropping its claim, by artificially imposing consensus, by ignoring conflicting viewpoints, or even by killing the adversary. Conflict can be resolved justly, but only by practices that respect the principle of adversarial argument, hearing the other side.

These arguments apply straightforwardly to the adversary system in law and allow us to better understand its strengths and weaknesses. The institutional strength of the adversary system is that giving parties sole responsibility for presenting their own cases arranges incentives so that every point of view gets investigated and presented as fully and sympathetically as possible. ${ }^{26}$ From the standpoint of decisional accuracy, partisan advocacy ensures that salient arguments are not overlooked. From the standpoint of respect for human variety, giving full voice to all positions is more just. We may put it the other way around: to exclude or silence voices makes the human world less just. Whatever harmony results is an illusion, a suppression of conflict-and justice is conflict.

The distinctive virtue of the adversary system lies in its ability to elicit more voices and more input than alternative systems. Even critics of the adversary system concede the importance of this virtue. ${ }^{27}$ However, focusing exclusively on this virtue idealizes the system too much. The problem is that the adversary system also gives parties incentives to keep bad facts and opposing viewpoints out of the system. Try at all costs to keep dangerous evidence out of hostile hands. If you cannot do that, try to have it

26. Exactly the same concerns underlie Lon Fuller's several attempts to justify the adversary system. For exposition and critique of Fuller's arguments, see generally David Luban, Rediscovering Fuller's Legal Ethics, published concurrently in 11 Geo. J. Legal Ethics 801, 819-28 (1998), and Rediscovering Fuller: Essays on Implicit LaW and InStitutional Design 193 (Willcm J. Wittevcen \& Wibren van der Burg eds., 1999).

27. Thus, for example, Jerome Frank, whose 1949 classic Courts on Trial remains one of the most searching critiques of the adversary systcm, admitted that adversaries "sometimes do bring into court evidence which, in a dispassionate inquiry, might be overlooked." JEROME FranK, COURTS ON Trial: Myth and Reality in American Justice 80 (1949). John Langbein, a contemporary critic of the adversary system, approvingly quotes this passage from Frank in an article largely critical of adversarial civil procedure. See John H. Langbein, The German Advantage in Civil Procedure, $52 \mathrm{U}$. CHI. L. REv. 823, 834-35 (1985). My own critique of the adversary system also agrecs that "[t]he legal system must ... allow us to articulatc our view of the facts and the law in court: that is why we have an adversary system in which parties present their own cases, rather than, say, an official inquiry into the matter conducted by the state." LuBAN, supra note 9 , at 85 . See $i d$. at $68-92$ for my critique of the adversary system. 
excluded from trial. And, if that fails, force the other side to use up their money and throw in their cards. Every trial lawyer understands the strategy, but it is an easy point for theorists enamored of the adversary system to overlook. A few examples will illustrate the extent to which these strategies are not only employed, but accepted.

In recent years, some American jurisdictions have begun experimenting with a rule permitting jurors to question witnesses directly. Although there may be a lot wrong with this rule, the benefits of allowing jurors to ask directly about facts they need to make a decision are obvious, and the experiment seems plainly worth trying. However, the president of a lawyers' organization was horrified at the idea. Why? "You work very hard to keep certain information out of the trial. Then all of your finesse and art and technique are thrown out the window when a juror comes in and asks, 'Where were you on the night in question?"' 28 Although to most lawyers this might be an obvious response, notice that the objection to the rule is that it might let vital information into the hearing. Apparently, his version of the principle of adversary argument is "hear both sides-but only if I get to control what the witnesses say."

Another example is the well-known Fisons case, in which the Washington Supreme Court sanctioned a prominent Seattle law firm, Bogle and Gates, for discovery abuse. ${ }^{29}$ In a products-liability case, the firm artfully dodged discovery requests for smoking-gun documents without ever letting anyone know that was what it was doing-until a whistleblower spilled the beans to plaintiff's counsel. ${ }^{30}$ The Washington Supreme Court imposed massive sanctions after coneluding that, given Bogle and Gates's evasiveness, "no conceivable discovery request could have been made ... that would have uncovered the relevant documents . . .."3l What was remarkable about Fisons was not the legal issue or the result. Rather, it was the testimony of fourteen legal-ethics experts that the law firm's tactics represented good litigation practice. Indeed, three of the experts said that discovery evasiveness is required by the duty of zealous advocacy. ${ }^{32}$ If the experts are wrong about this (as the court thought and as I think as

28. Bill Miller, Making a Case for Questions from Jurors: Process, Rare Now, Is Judicial Trend of Future, Backers Say, WASH. Post, May 26, 1997, at Al (statement of Colin Dunham, President, Independent Public Defender Association).

29. See Wash. State Physicians Ins. Exch. v. Fisons Corp., 858 P.2d 1054 (Wash. 1993).

30. The firm construcd discovery requests narrowly and hypertechnieally to avoid turning over smoking-gun documents. For example, the firm withheld documents about a product because they wcre filed under the name of a diffcrent product containing the same active ingredient, and Bogle and Gates read the discovery request to be file-specific. Id. at 1083 . Furthermore, the firm objected on grounds of irrelevance to discovery directed at the files of the other product. Id. Worsc, the firm kept to itself the fact that it was construing discovery requests via theological hairsplitting. To the outside world, it simply denied that it had any documents that met the plaintiffs' specifications. Id. at 1080-84.

31. Id. at 1083.

32. See Stuart Taylor, Jr., Sleazy in Seattle, AmEr. Law., Apr. 1994, at 5. 
well), the adversary system can still be faulted for creating incentives for litigato s to hide the ball. If, on the other hand, the experts are right, the fault in the adversary system runs far deeper than bad incentives. The fault is that, paradoxically, instead of maximizing high-quality input, our adversary system of litigation builds in a principle of zeal that requires lawyers to hide the ball. ${ }^{33}$

Less familiar, but equally important, is the adversarial attempt to exclude voices rather than information from the process. For example, in a typical Strategic Lawsuit Against Public Participation ("SLAPP suit"), citizens protesting corporate policies or actions get sued by a corporation for defamation or tortious interference with business. An activist who testifies against a real estate developer at a zoning-board hearing, or complains about incompetent teachers to the school board, or collects signatures for a petition, may find herself hit with a SLAPP suit. Even though $80 \%$ of SLAPP suits are dismissed before trial, the aim is not legal victory but intimidation. Defendants facing ruinous legal bills and the risk of substantial personal liability agree to cease protest activities in return for having the SLAPP suit dropped. ${ }^{34}$ By driving the other side out of the forum, this tactic represents a direct violation of audi alteram partem.

These examples illustrate that philosophers such as Hampshire and Lon Fuller, who view the adversary system only as a tool for the benign purpose of maximizing input and voice, are being naïve about the operation of our adversary system. The closest approximation of their ideal is appellate argument, where advocates debate the interpretation of legal materials and a written record that are open to everyone's inspection. Judges invariably find it easier to decide legal issues after hearing first-rate advocates present forceful cases for both sides, and obviously the prospect of advocates using chicanery to conceal the law is virtually nonexistent. The adversary system of evidence-taking is a far more mixed bag, in which efforts to inject input into the system mingle promiscuously with strategic manipulations to keep information out. In this system, even the selection of voices that gain a hearing is hostage to adversarial manipulation. But the point of this Essay is not to propose replacing our adversary system. My point is that an adversary system with only one adversary is an adversary system in name alone, and in that case, all justifications are simply beside the point. When judges and legislatures create doctrines that enable well-funded parties to take out the other side's lawyer, they undermine

33. Bogle and Gates, at any rate, certainly seemed to believe this. Two years after Fisons a federal judge sanctioned the firm for a similar discovery violation. See Alex Fryer, Clout of State's Big Law Firms Wards Off Misconduct Cases, Seattre Times, May 3, 1998, at F1.

34. See George W. Pring \& Penelope Canan, SlapPSs: Getting Sued for Speaking Out (1996); see also Ralph Nader \& Wesley J. Smith, No Contest: Corporate Lawyers and the Perversion of Justice in America 158-92 (1996). 
basic fairness and turn the adversary system into a system of procedural injustice.

\section{SILENCING DoctRINES}

My specific topic, then, is the deliberate attempt to keep progressive voices out of the legal system by taking away their lawyers. ${ }^{35}$ For the reasons examined in the preceding Part, it is unsurprising that opposing parties will take away their adversaries' lawyers if they can. The adversary system provides them powerful incentives to do so. Their effort cannot succeed, however, without legal weapons. These I call "silencing doctrines." Silencing doctrines include statutes, rules, and judicial decisions that allow opponents to attack the funding or restrict the activity of their adversaries' advocates.

In recent years, a pattern of silencing doctrines has begun to emerge challenging - to greater or lesser extent-virtually every principal source of support for low-income public-interest lawyering: the LSC, state IOLTA programs, law school clinics, and fee awards in civil rights cases. Most of these doctrines are the handiwork of judicial and congressional conservatives, and one originates in lawsuits from a probusiness publicinterest law firm that has made its mission defunding public-interest lawyers it dislikes. Of course it would be just as wrong if the doctrines came from the Left to silence the Right. Someday they may, and then the same criticisms would apply. For thc criticism concerns procedural injustice, regardless of its political orientation.

\section{A. The 1996 Legal Services Corporation Restrictions}

The single biggest source of funding for poor people's lawyers is the Legal Services Corporation, with a fiscal year 2001 budget of $\$ 330$ million ( $\$ 310$ million for client representation). In 1998, this budget funded 3,590 attorneys at an average salary of just under $\$ 40,000$, along with 4,637 paralegals. ${ }^{36}$ The pathetic numbers-one underpaid legal-services lawyer per 10,000 poor people - have not prevented decades of political assaults on

35. My colleague Phil Schrag has emphasized to me that many other legal doctrines function to keep poor people and progressives out of court. These include bond requirements, the requirements of personal jurisdiction, the noncollectibility of judgments, bars to judicial review, burden-of-proof rulcs, standing requirements, the political-question doctrine, Eleventh Amendment immunity, and the lack of a constitutional right to civil legal aid. See Lassiter v. Dep't of Soc. Servs., 452 U.S. 18 (1981) (establishing a stringent balancing test to determine when lack of legal representation in civil cases violates due process). My exclusive focus in this Essay on doctrines that silence public-interest clients by restricting or defunding their lawyers is not meant to suggest that these are the only, or even the most important, legal rules that disadvantage public-interest clients.

36. See LSC websitc, at http://www.lsc.gov/press/pr_sl.html. 
the program, including the outright lie that poor people have no trouble finding a free lawyer. ${ }^{37}$

Restrictions on the use of LSC funding have always existed. From the beginning of the program, Congress prohibited LSC recipients from using their federal funds on volatile political issues like abortion, school desegregation, and the military draft. Although this often frustrated progressives, it made a certain amount of sense to keep a eontroversial program such as LSC out of the most hot-button political issues of the day. Moreover, LSC lawyers could still advocate on these issues provided they did not use federal funds to do so. These restrictions could be weakly justified on grounds of liberal neutrality, inasmuch as they kept federal funds out of advocacy over divisive issues. ${ }^{38}$ So long as there were other funds and other advocates available, the restrictions were tolerable, and only minimally offended the principle audi alteram partem.

In 1996, however, Congress enacted restrictions on legal-services lawyers that went much further. Not only do they prohibit LSC recipients from taking on certain issues, but they also forbid them from representing entire classes of clients. These include whole classes of aliens, many of whom are legal. The new regulations likewise prohibit the representation of all incarcerated people, including those not convicted of a crime, and those whose cases have nothing to do with why they are in jail, as, for example, in parental-rights lawsuits. ${ }^{39}$ The restrictions also prevent LSC attorneys from using specific procedural devices or arguments. They cannot attempt to influence rulemaking or lawmaking, participate in class actions, request attorney's fees under applicable statutes, challenge any welfare reform, or defend anyone charged with a drug offense in a public-housing eviction proceeding. ${ }^{40}$ Furthermore, LSC grant recipients must file statements revealing the identity of their clients and stating the facts of the case, and these statements must be made available "to any Federal department or agency that is auditing or monitoring the activities of the Corporation or of the recipient." ${ }^{\prime 41}$

Perhaps the most devastating regulation, however, is Congress's prohibition on LSC recipients using their nonfederal funds for these prohibited activities. This requirement had a drastic effect. A legal-aid office could no longer accept an LSC grant if it did any prohibited legal work. This

37. On political attacks against the LSC, see, for example, Hidden Agendas: What Is Really Behind AtTacks on Legal Aid Lawyers? (Brennan Center for Justice, New York, NY, 2001), available at http://www.brennancenter.org/programs/downloads/article7.pdf; LuBAN, supra note 9, at 297-302.

38. The justification is weak because on issues like the draft and voting rights, the government itself was a party.

39. See Pub. L. No. 104-134, $\$ 504$ (11), (15), 110 Stat. 1321-54 (1996).

40. Id. $\$ \$ 504$ (1)-(4), (7), (13), (16), (17).

41. Id. $\$ 504$ (8). In some circumstances this could include hostile congressmen trolling for redmeat anecdotes of the Willie Horton variety. 
provision forced legal-services providers to split into separate organizations with separate offices, one receiving federal funds and abiding by the restrictions, the other maintaining its freedom of action at the cost of its LSC grant. LSC enacted "program integrity" regulations to implement this restriction by ensuring that the two offspring organizations maintained physical and financial separation. The result was bifurcated organizations substantially weaker than the initial organization. Some organizations had to purchase duplicate computer systems and hire duplicate staff. Some locales could afford only a restricted office, so that clients with the "wrong" cases were forced to travel hundreds of miles to find counsel or, more realistically, do without. In hundreds of ongoing cases, restricted LSC lawyers had to withdraw. ${ }^{42}$

The congressional restrictions are silencing doctrines, preventing attorneys from advocating for people who have no recourse to non-LSC advocates. Opponents of progressive lawyers quickly took advantage of the regulations. For example, when the restrictions went into effect, New York legal-services lawyer David Udell was helping to monitor an alreadysettled class action against a federal agency. The LSC threatened that if he continued to participate in the case, it would defund every legal-services lawyer in New York City and fire every employee. ${ }^{43}$ The LSC backed down when Udell filed a constitutional challenge to the restrictions, in the form of a motion to withdraw conditional on the restrictions being upheld. In a face-saving explanation, the LSC stated that Udell's participation in an already-settled class action did not violate the new restrictions because his role was nonadversarial. ${ }^{44}$ But later, when Udell informed the monitoring court that the defendant had violated the settlement,

[t]he defendant's counsel (a lawyer in the federal programs branch of the Department of Justice) reported my action to LSC. LSC then declared that my letter to the court was "adversarial" and ordered me off the case on pain of defunding all legal services programs in New York City, even though the merits of the underlying case had been resolved years earlier. ${ }^{45}$

Again, Udell backed the Corporation down through legal action, and the LSC contented itself with merely docking his pay for going to court against it. ${ }^{46}$ Udell fared less well in another class action, when the LSC ordered him out but the judge ordered him to stay in the case while at the same time refusing to prevent LSC from taking disciplinary action against Udell

42. See David S. Udell, The Legal Services Restrictions: Lawyers in Florida, New York, Virginia, and Oregon Describe the Costs, 17 YALE L. \& POL'Y Rev. 337 (1998).

43. See id. at 342. Udell is no longer a legal-services lawyer; he is now deputy director of NYU's Brennan Center, which has spearheaded litigation challenging silencing doctrines.

44. Id.

45. Id. at 342-43.

46. Id. 
or other legal-services lawyers in New York. ${ }^{47}$.Udell had no recourse but to work on a part-time basis and handle the class action, during his off hours, for no pay. ${ }^{48}$ Although this example makes the LSC seem like the heavy, the LSC was only doing what Congress wanted it to do.

Do these restrictions compel legal-services lawyers to practice law unethically? The American Bar Association ("ABA") Model Rules of Professional Conduct ("Model Rules") forbid lawyers from letting a nonclient who pays them interfere with their professional judgment on the client's behalf. ${ }^{49}$ Suppose a legal-aid lawyer wants to go after a revolvingcredit scam that has bilked 1,000 poor people out of $\$ 20$ each. She cannot very well litigate 1,000 individual cases, and her best professional judgment screams "class action!" But the restrictions forbid class actions. To take another example, the restrictions require legal-services lawyers to forego whatever negotiating leverage the possibility of statutory attorney's fees provides in settlement talks. That may hurt the lawyer's effectiveness as well as her office finances. Are such lawyers then violating the Model Rules by abiding by the regulations? The answer is no, because attorneys have an obvious recourse: they can simply decline to accept cases that are best pursued through forbidden means. Nothing prevents the legal-services lawyer from turning down the revolving-credit case that needs a class action, and to comply with both the congressional restrictions and the Model Rules, she may well turn down the case. The perverse result: the more poor people a legal problem affects, the less likely they are to find a lawyer to represent them. ${ }^{50}$ If the client is an inmate in a mental institution complaining of abusive treatment, then the legal-services lawyer has to warn the client that he may be in danger of having his identity revealed. ${ }^{51}$ If having such a frightening conversation with an emotionally fragile client

47. Id. at 343 .

48. Id. at 343-44.

49. Model Rule 5.4(c) states: "A lawyer shall not permit a person who ... pays the lawyer to render legal services for another to direct or regulate the lawyer's professional judgment in rendering such legal services." Model Rules of Prof'L Conduct R. 5.4(c) (2002). Similarly, Model Rule $1.8(\mathrm{f})(2)$ provides that "A lawyer shall not accept compensation for representing a client from one other than the client unless there is no interference with the lawyer's independence of professional judgment or with the client-lawyer relationship." Id. R. 1.8(f)(2).

50. A less-drastic approach would require the legal-services lawyer to obtain the elient's prior consent to a representation that avoids forbidden means, such as class actions. Model Rule 1.2(c) permits a lawyer to limit the objectives of the representation if the client consents after consultation. See id. R. 1.2(c). Howcver, a lawyer cannot ask a client to limit the representation in a way that violates another Model Rule. For example, a lawyer cannot ask the client to consent to incompetent representation. Here, asking the client to consent ex ante to a representation that foregoes the most effective legal strategy comes perilously close to asking the client to consent to malpractice.

51. Section 504(8)(B) of the 1996 restrictions, which requires disclosure of client identity, also provides for gag orders if "neeessary to prevent probable, serious harm to such potential plaintiff." But it is the client who must pursue the gag order, and the lawyer is obligated to explain this to the client. The lawyer must also explain to the client that, in pursuing the gag order, he risks that it will be denied and that his identity will be disclosed to his persecutors. 
poisons the client-lawyer relationship, then the lawyer cannot take the case. The ABA went so far as to say that legal-services lawyers must warn all their clients at the first interview that if they get jailed, the lawyers will have to drop them. ${ }^{52}$ If you think your relationship with your client, perhaps a prim ninety-seven-year-old grandmother, will be harmed by telling her that you will have to cease representing her if she is incarcerated, then do not take the case.

While permitting legal-services lawyers to avoid violating the Model Rules of Professional Conduct, these results are deeply problematic from an ethical standpoint. Viewed in the most favorable light, the 1996 restrictions reprcsent Congress's legitimate attempt to ensure that legal-services lawyers accept only cases that carry no tincture of political advocacy or social engineering: If class actions are proscribed, it is because class actions are a favorite device of structural reformers; if attorney's-fees cases are proscribed, it is because these tend to be awarded in environmental or civil rights cases; if aliens or prison inmates cannot bc represcnted, it is because these are politically controversial groups. However, those poor enough to meet legal-aid eligibility criteria are extremely unlikely to have the money to hire a lawyer, and non-LSC-funded public-interest lawyers are rare. Thus, the overwhelming presumption must be that the vast majority of cases that legal-scrvices lawyers turn down will never be brought by anyone.$^{53}$ It follows, then, that the restrictions ensure that entire subgroups of low-income people will never be heard in the legal system, including many aliens, all prisoners (including those in jail for only a brief time and those whose incarceration has nothing to do with their legal-services case), public-housing residents accused (perhaps falsely) of drug offenses and facing eviction, and clients for whom a class action is the most effective means of representation.

These restrictions are silencing doctrines. Some of them-for example, the ban on attorney's-fees cases, or the ban on class actionsstraightforwardly make the activities of progressive public-intcrest lawycrs more expensive. Some of them silence the lawyers less directly by steering them away from otherwise-worthwhile cases that threaten their funding.

52. This was the startling conclusion of the ABA's cthics committee. See ABA Comm. on Ethics and Prof'l Responsibility, Formal Op. 96-399 (1996). For a forceful dissent from this view, see Alan W. Houseman, Restrictions by Funders and the Ethical Practice of Law, 67 FordHAM L. REv. 2187, 2237 (1999) (arguing that the notice requirement suggested in Formal Opinion 96-399 "does not appear to be necessary" and is unjustified beeause it will have a "potentially negative impact on the attorneyclient relationship" by insulting many clients).

53. This is a matter of some dispute. Recall that PERLS reports about $\$ 364$ million in non-LSC, non-IOLTA legal-services funding in 2001. See PERLS, supra notc 5. It is unclear, however, how much of this money (particularly the biggest source, $\$ 200$ million in public funds) goes to organizations that also are receiving LSC funds and, thus, cannot put it to unrestricted use. My guess is that the vast majority of these funds goes to restricted organizations, the same legal-aid providers that receive LSC grants. 
Furthermore, the overarching requirement that nonfedcral funds cannot be used for proscribed activities makes representation of the poor more difficult for legal-services lawyers by forcing them to bifurcate and weaken their organizations, thereby interrupting communications and increasing overhead.

Disappointingly, neither the Bar nor the legal-services establishment offered any organized protest when the 1996 restrictions were cnactedunlike a similar assault in 1981, when law school deans and the organized bar united in protest against efforts to abolish the LSC. The reason was pure fear that Congress, in the heady days of Newt Gingrich's revolution and the Contract With America, would simply abolish the LSC. Even attempts to challenge the restrictions in court were discouraged by many people in the legal-services community. ${ }^{54}$ The ABA Ethics Committee's response was entirely typical: instcad of writing a formal opinion insisting that the restrictions violate the ideals of the legal profession, it chose instead to write an opinion insisting that a legal-services grant recipient could practice law ethically by abandoning clients to keep its funding intact. The advice is undoubtedly accurate: declining cases is a sure-fire way to stay out of trouble. Nevertheless, the LSC restrictions undercut the legal profession's ideals because they instruct legal-services lawyers not to represent certain classes of clients, regardless of whether they have meritorious or important claims. The ideals this violates are set out in the ABA's Model Code of Professional Responsibility ("Model Code"), the predecessor to the Model Rules of Professional Conduct. The Model Code states that "the objective of the bar [is] to make legal services fully available." ${ }^{55}$ It warns lawyers against turning down cases, even those "which may be unattractive both to him and the bar generally." 56 The Model Code reminds attorneys that "[h]istory is replete with instances of distinguished and sacrificial services by lawyers who have represented unpopular clients and causes. Regardless of his personal feelings, a lawyer should not decline representation becausc a client or a cause is unpopular or community reaction is adverse." ${ }^{57}$ Given these admonitions, one might have hoped that the ABA's formal opinion would have criticized the 1996 restrictions, which require LSC-funded lawyers to decline cases because the client is an alien or in jail. A forthright statement by the ethics committee of the nation's largest organization of lawyers that the restrictions are inconsistent

54. I owe this information to conversations with many lawyers involved in the process. The pusillanimous rcsponse of legal-services supporters calls to mind an old Yiddish joke. Abe and Moishe are about to be executed by a Cossack firing squad. The Cossack captain offers them blindfolds, but Abe angrily says, "No blindfold!" Moishe plueks anxiously at Abe's sleeve, and whispers in anguish, "Abe, don't make trouble!" Legal-services supporters decided not to make trouble.

55. MOdel CODE OF Prof'l ResPonsibILITY EC 2-26 (2002).

56. Id.

57. Id. EC 2-27. 
with professional ideals might have provided ammunition for legal challenges to the restrictions. One can only conclude that the ABA committee decided that, for the good of the legal-services lawyers, capitulation was the better part of valor. ${ }^{58}$

Lawsuits eventually were brought challenging the LSC restrictions, although the results to date have been discouraging. An unconstitutionalconditions challenge to the restrictions failed in the Ninth Circuit, as did an equal-protection challenge. ${ }^{59} \mathrm{~A}$ due process and First Amendment challenge in the Second Circuit also failed, except for one portion of it, directed against the ban on legal arguments against the validity of welfare laws. ${ }^{60}$ The 1996 restrictions prohibited LSC lawyers from arguing that welfare laws are invalid but not from arguing that they are valid. The Second Circuit held-and the U.S. Supreme Court agreed-that this remarkable restriction on what legal-services lawyers may say in court was not viewpoint-neutral, and thus it violated the First Amendment. ${ }^{61}$ Although the objection seems decisive, the victory affects only a small part of the regulation. The statute remains intact to silence legal-services lawyers in the other ways we have examined. Hear the other side-except when the other side is an indigent who is also a prisoner or alien, a member of a class, someone who objects to a rulemaking process, or someone who would be adversely affected by a lawyer who abides by the restrictions. In that case, defund his lawyer.

\section{B. The Challenges to IOLTA Programs}

IOLTA programs provide the second biggest source of funds for legal-aid lawyers, after the LSC. $^{62}$ Lawyers are required to maintain trust accounts for client money that they hold. ${ }^{63}$ When the amount is large, or held for a significant time period, attorneys open an interest-bearing

58. Admittedly, and in my view disgracefully, neither of the admonitions I have quoted from the Model Code were incorporated into the Model Rules. Perhaps the ABA committee that wrote Formal Opinion 399 believed that it has no mandate to issue dicta that go beyond what the Model Rules requires. However, this has not been the uniform practiee of the committee on less incendiary issues. For example, in 1992 the committee issued a formal opinion on the vexed question of what a lawyer should do when an adversary sends her confidential documents by mistake. The committee acknowledged that "[a] satisfactory answer to the question posed cannot be drawn from a narrow, literalistic reading of the black letter of the Model Rules." ABA Comm. on Prof'I Conduct, Formal Op. 368 (1992). It concluded that the lawyer should return the documents unread, even if reading them might help the client, basing its conclusion on a "larger, and more fundamental, framework" than the Model Rules; namely, doing the right thing. Id.

59. See Legal Aid Soc. of Haw. v. Legal Servs. Corp., 145 F.3d 1017 (9th Cir. 1998).

60. Velasquez v. Legal Servs. Corp., 164 F.3d 757, 764-73 (2d Cir. 1999).

61. See Velazquez v. Legal Servs. Corp., 531 U.S. 533 (2001).

62. PERLS, supra note 5.

63. See, e.g., Model Rules of Prof'L Conduct R. 1.15(a) (2002) (requiring lawyers to hold client funds in an account separate from the lawyer's own funds); RESTATEMENT (THIRD) OF THE LAW GOVERNING LAWYers $\$ 44(a)(2000)$. 
savings account in the client's behalf, but when the amount of money the lawyer holds for clients is small, or the money is held for a short period of time only, the administrative cost of getting the interest to clients would devour the interest and might actually cost the client money. In such cases, the attorney deposits client funds in a demand account, that is, an account from which funds may be obtained on demand. Until 1980, banking law prohibited interest payments on demand accounts. ${ }^{64}$ In 1980 , Congress amended the law to permit interest-bearing demand accounts, but only for "funds in which the entire beneficial interest is held by one or more individuals or by an organization which is operated primarily for religious, philanthropic, charitable, educational, political, or other similar purposes and which is not operated for profit." ${ }^{25}$ States responded to the new law by creating IOLTA programs: nonprofit foundations to fund low-income legal services, financed by the interest on lawyer's demand trust accounts. Lawyers participating in IOLTA programs pool client funds that are too small or held for too short a time to generate collectible interest for the client in an IOLTA account, where the interest goes to the nonprofit foundation funding low-income legal services. Client funds that are capable of generating collectible interest for the client-that is, interest that would not be devoured by the transaction costs of getting it to the client-must still be deposited into a separate savings account for the client, not into the IOLTA account.

The idea was ingenious. The clients could not get the interest on small or short-term lawyer-held funds because transaction costs would gobble it up. Because no one else could get the interest either, it all went to the banks by default. As one Texas judge quipped, IOLTA takes from the banks and gives to the poor. ${ }^{66}$ IOLTA programs generated more than $\$ 125$ million a year for indigent legal services in 2001. ${ }^{67}$ Almost all were enacted by the states' highest courts under their rulemaking authority. ${ }^{68}$ All fifty states and the District of Columbia have IOLTA plans, and half of them are mandatory. ${ }^{69}$

Almost from the beginning, IOLTA faced constitutional challenges from disgruntled lawyers, clients, and activists who objected to the idea of helping legal-services lawyers. ${ }^{70}$ Generally based on the Takings Clause,

64. 12 U.S.C. $\$ \S 371 \mathrm{a}, 1464(\mathrm{~b})(1)(\mathrm{B}), 1828(\mathrm{~g})(2000)$.

65. Id. $\S 1832(\mathrm{a})(2)$.

66. See Paulsen v. State Bar of Tex., 55 S.W.3d 39, 48 (Tex. App. 2001).

67. See PERLS, supra note 5.

68. See Phillips v. Wash. Legal Found., 524 U.S. 156, 159 n.1 (1998).

69. As of 2001, twenty-six states have mandatory IOLTA programs, twenty-two have opt-out programs, and three states maintain voluntary programs. See Ind. State Bar Assoc., IOLTA Fact Sheet, at $\mathrm{http}: / /$ www.inbar.org/content/iolta/ioltaqal .asp (last visited Oct. 7,2002).

70. See, e.g., Cone v. State Bar of Fla., 819 F.2d 1002 (11th Cir. 1987) (no taking of plaintiff's property); Carroll v. State Bar of Cal., 166 Cal. App. 3d 1193, 1204-08 (Cal. Ct. App. 1985) (finding 
the early challenges failed because IOLTA programs keep only interest that would not exist if the clients could get it back. However, the judicial and political climates have changed, and the U.S. Supreme Court is currently reconsidering whether IOLTA statutes violate the Takings Clause of the federal Constitution. ${ }^{71}$

\section{IOLTA and the Takings Clause}

The Washington Legal Foundation ("WLF"), a conservative publicinterest law foundation and, as we shall see, a stalwart champion of silencing doctrines, challenged IOLTA statutes in Massachusetts, Texas, and Washington. The WLF lost in Massachusetts, ${ }^{72}$ but soon won a major victory in its Texas litigation when the United States Supreme Court held in a five-to-four decision in Phillips v. Washington Legal Foundation that unrecoverable interest on client funds remains the property of the client. ${ }^{73}$ The Court remanded the case to determine whether IOLTA amounts to an unconstitutional taking of that property without just compensation. ${ }^{74}$ On remand, the Texas district court found no taking, relying on the U.S. Supreme Court's observation that "[t]he Fifth Amendment does not proscribe the taking of property; it proscribes taking without just compensation." ${ }^{15}$ The court found no taking without just compensation because a client with money in an IOLTA account is "in as good a position as he would have enjoyed without the alleged taking." Circuit Court of Appeals reversed this decision and held that the Texas Supreme Court's justices could be cnjoined from disciplining attorneys who refuse to deposit client funds in IOLTA accounts. ${ }^{77}$ The Fifth Circuit

mandatory IOLTA program does not violate Takings Clause, Equal Protection Clause, or Sixth Amendment right to counsel).

71. Wash. Legal Found. v. Legal Found. of Wash., 122 S. Ct. 2355 (2002) (granting writ of certiorari).

72. See Wash. Legal Found. v. Mass. Bar Found., 993 F.2d 962 (1st Cir. 1993).

73. 524 U.S. 156 (1998).

74. See $i d$. at 172 . The Takings Clause provides that private property shall not "be taken for public use, without just compensation." U.S. Const. amend. V. The Phillips Court determined that the common-law rule "interest follows principal" applies to interest in lOLTA accounts, and thus that the interest belongs to the clients. Phillips, 524 U.S. at 165. However, the Court "express[es] no view as to whether these funds have been 'taken' by the State; nor do we express an opinion as to the amount of 'just compensation,' if any, due respondents." Id. at 172.

75. Wash. Legal Found. v. Tex. Equal Access to Justice Found., 86 F. Supp. 2d 624, 637 (W.D. Tex. 2000) (quoting Williamson County Reg'l Planning Comm'n v. Hamilton Bank of Johnson City, 473 U.S. 172, 194 (1985)).

76. Id. at 638. To support its analytic approach, the district court relied on two dicta from the U.S. Supreme Court: first, "the question is what has the owner lost, not what has the taker gained," $i d$. at 637 (quoting Boston Chamber of Commerce v. Boston, 217 U.S. 189, 195 (1910)), and second, that in determining just compensation a court must seek to place a claimant "in as good a position pecuniarily as if his property had not been taken," id. at 638 (quoting United States v. 564.54 Acres Land, 441 U.S. 506, 510 (1979)).

77. Wash. Legal Found. v. Tex. Equal Access to Justice Found., 270 F.3d 180, 194-95 (5th Cir. 2001). 
emphasized that "a client's rights to possess, control, and dispose of the interest earned on his funds are valuable rights, regardless of whether the interest has economic value." 78 The amount of compensation needed to restore these rights would consist of all the IOLTA interest (that is, a dollar of compensation for every dollar of interest taken) $;{ }^{79}$ and because a mechanism to restore the interest dollar for dollar would make the whole IOLTA exercise pointless, injunctive relief is appropriate to prevent the taking. ${ }^{80}$

Meanwhile, the WLF prevailed before a Ninth Circuit panel, which found an unconstitutional taking and remanded the case to determine just compensation. ${ }^{81}$ However, the Ninth Circuit sitting en banc reversed the panel decision, holding that IOLTA plans do not constitute a taking, and that in any event, the just compensation would be zero. ${ }^{82}$ The Ninth Circuit en banc opinion also remanded the case to the District Court to decide a First Amendment claim by the IOLTA protestors that their mandatory contributions to pooled accounts are unconstitutional compelled speech and association. ${ }^{83}$ The WLF appealed to the U.S. Supreme Court, and in June 2002 the Court granted certiorari. ${ }^{84}$ The case was argued in December 2002, and the Supreme Court's decision may lay the issue to rest.

I do not in this Essay aim to offer a full-fledged analysis of the takings arguments, but it is worthwhile trying to understand the germ of the issue. The Phillips Court held that interest belongs to the client even when the client cannot collect it. As Justice Souter complained in his dissenting opinion,

the Court's limited enquiry has led it to announce an essentially abstract proposition; even on the assumption that the proposition is a correct statement of the law, it may ultimately turn out to have no significance in resolving the real issue raised in this case, which is whether the Interest on Lawyers Trust Account (IOLTA) scheme violates the Takings Clause of the Fifth Amendment. ${ }^{85}$

Justice Souter's concern proved prescient, because the abstract proposition that IOLTA interest belongs to the client conjured up intricate questions

78. Id. at $187-88$.

79. Id. at 193-94.

80. To reach this conclusion, the Court of Appeals constructed a complex argument, drawing on Supreme Court precedents that permit equitable relief in certain situations when claimants are entitled to compensation but no mechanism exists for them to collect it, and distinguishing other Supreme Court precedent that seemingly denies injunctive relief in takings cases. Id. at 190-94.

81. Wash. Legal Found. v. Legal Found. of Wash., 236 F.3d 1097 (9th Cir. 2001).

82. Wash. Legal Found. v. Legal Found. of Wash., 271 F.3d 835 (9th Cir. 2001) (en banc). The decision provoked a spirited dissent from Judge Kozinski, joined by Judges Kleinfeld, Trott, and Silverman. See id. at 864 (Kozinski, J., dissenting).

83. Id. at 864. None of the previous appellate courts found it necessary to address this issue because the protestors prevailed on their Fifth Amendment claims.

84. Wash. Legal Found. v. Legal Found. of Wash., 122 S. Ct. 2355 (2002) (granting writ of certiorari).

85. Phillips v. Wash. Legal Found., 524 U.S. 156, 172 (1998) (Souter, J., dissenting). 
that have no answer-questions like "What is it to 'take' interest that the owner does not and cannot 'have'?" and "What is 'just compensation' when the owner is no worse off from having his interest 'taken'?" These may sound like genuine legal questions, but in reality they are little more than metaphysical brain-teasers on a par with "How many imaginary fat men are standing in the doorway?" Decades ago, Felix Cohen coined the phrase "transcendental nonsense" to describe issues that look like legitimate legal inquiries but in fact employ contentless abstractions that cannot be given content without arguing in a circle. ${ }^{86}$ Unfortunately, in law, metaphysical questions invite political answers: the gut fills in the blanks, and judges forced to decide the question reach whatever result they find congenial. The Texas district court that upheld IOLTA reasoned that since the owner could not have the interest, there was no uncompensated taking because the just compensation would be zero. ${ }^{87}$ The Fifth Circuit that reversed the decision explained that just compensation requires all the interest, and because the owner cannot collect it, his lawyer should not be required to deposit it in an IOLTA account. ${ }^{88}$ The two courts point to identical facts to support opposite conclusions - the telltale sign of transcendental nonsense. What brought matters to this sorry state?

To explain the Supreme Court's error and its consequences, I shall use the device of a fairy tale in the manner of Hans Christian Andersen. The tale I tell concerns a miser to whom the fairies gave a peculiar gift: a magic penny that turns to ashes unless the miser gives it away. If the miser tries to hoard the penny, or to spend it on himself-poof! It becomes a handful of ashes. But if he gives it to a person in need, the penny will never disappear. Malvina Reynolds has a song about this magic penny:

Hold it tight and you won't have any.

Lend it ... and you'll have so many

They'll roll all over the floor. ${ }^{89}$

The point of my fairy tale, of course, is that IOLTA interest takes the form of magic pennies: they do good if they are pooled and given away, as even the WLF concedes $;{ }^{90}$ but if their owner claims them, they disappear. I shall

86. Felix Cohen, Transcendental Nonsense and the Functional Approach, 35 CoLuM. L. Rev. 809 (1935).

87. See Wash. Legal Found. v. Tex. Equal Access to Justicc Found., 86 F. Supp. 2d 624, 643 (W.D. Tex. 2000).

88. See Wash. Legal Found. v. Tex. Equal Access to Justice Found., 270 F.3d 180, 193-94 (5th Cir. 2001).

89. Malvina Reynolds, The Magic Penny (Northern Music Co. 1955).

90. The WLF describes funding legal services for low-income clients as a "laudable public goal." Brief for Petitioners, 2002 U.S. LEXIS 4225, at*22, Wash. Legal Found. v. Legal Found. of Wash., 122 S. Ct. 2355 (2002) (No. 01-1325) [hereinafter WLF Petitioners' Brief]. One is of course entitled to doubt the sincerity of this concession. A September fundraising letter from the WLF to its supporters stated that it hopes to "deal a death blow to the single most important source of income for radical legal groups across the country," and added: "lt's an abomination that Iolta [sic] can take money that is 
call property that disappears unless it is given away "magic-penny property."

We can guess how the fairy tale continues. The miser cannot bear to give his penny to the beggar shivering in the street. He tries and tries, but his hand just will not unclench to drop the penny in the beggar's cup. The fairies whisper in his ear that the fate of his soul depends on his choice. The miser is about to give in, but suddenly he recognizes that the beggar is his old rival, fallen on hard times. "Nothing for you!" he shrieks. At that precise moment the beggar dies, and the penny turns to ashes in the miser's hand.

The law lets the miser hold back the penny because it is his. He has a property right in it, just as the Phillips Court says. ${ }^{91}$ But, because of the fairies' curse, it is the most seldom used of the entire bundle of property rights. It is the "spite right," the right occasionally used by vanquished people when they blow up their own city rather than permit their foes to occupy it. The spite right is the right to ruin your property to keep it out of someone else's hands.

The Ninth Circuit panel recognized the dynamics of spite in Washington Legal Foundation v. Legal Foundation of Washington, its IOLTA decision. The court paraphrases the mentality of IOLTA challengers as, "it is not so much that I want the $\$ 20$, though I do, as that I don't want the [IOLTA] donees to get it." $" 92$

Now, the defining fact about magic-penny property is that only spite rights and donative rights (that is, rights to give the property away) remain out of the entire bundle that ordinarily defines property. I have no wish to deny that spite rights legitimately belong among the bundle of property rights we recognize; they are a special case of the right to exclude others from the use of our property, just as donative rights are a special case of the right to alienate our property. The rights to exclude and alienate are central components of private property as the common law understands it. But I would venture two observations. First, it seems likely that societies tolerate spite rights only as rare and special cases. It seems inconceivable that property law would include this right to waste a holding merely to spite those who might make good use of it if wasting holdings out of spite were a common practice. After all, the principal theoretical justification of

rightly the property of Americans like you and me and use that money to support programs we oppose, that stand in direct opposition to everything we believe in." Linda Greenhouse, Method of Legal Services Financing Is Challenged Before Supreme Court, N.Y. Times, Dec. 10, 2002, at A24 (quoting WLF fundraising letter). The fact that an organization which regards IOLTA as an "abomination" and its recipients as enemies of "everything we believe in" chooses to describe the same activities as a "laudable public goal" in its brief carries an obvious implication: the WLF understands quite clearly how out of line its ideology is even with an audience as conservative as the U.S. Supreme Court.

91. See Phillips, 524 U.S. at 172.

92. 236 F.3d at 1105 . 
private property is that assets tend to deteriorate when no one has property rights in them. ${ }^{93}$ According to this justification, property is a worthwhile social institution because property rights maintain the world by giving people incentives to care for their own bits of it. And people care for their property because they foresee beneficial enjoyment of it-a possibility that does not exist with magic-penny property. In this way, the spite right actually clashes with the theory of private property as an incentive to asset preservation. If all property could be only donated or destroyed, like magic pennies, we would recognize only the right to give it away. Property rights are supposed to discourage the alternative-destruction.

The Court in Phillips asserted that in finding a property right in IOLTA interest, it was merely upholding the old common-law rule that interest follows principal..$^{94}$ But in fact, the Court was upholding the spite right, the only right that remains in magic-penny property whose owner will not give it away, and the only right that clashes with the underlying theory of private property. The Phillips Court's focus on the sanctity of spite rights seems like a classic case of letting the tail wag the dog. It would have been easy to uphold the rule that interest follows principal while carving out an exception for interest that the owner cannot collect.

A second observation follows from the nature of magic-penny property. The only taking in IOLTA programs is of the client's spite right and donative right in his interest. These property rights are the only ones remaining; and the owner cannot even give his money to a charity of his choice, because the same overhead costs that would eat up the interest if he tried to collect it for himself will also eat it up if he tries to give it away to a third party other than IOLTA's recipients. ${ }^{95}$ In practical effect, then, only

93. This formulation of the theory comes from John Rawls, The LaW of Peoples 39 (1999): "As I see it the point of the institution of property is that, unless a definite agent is given responsibility for maintaining an asset and bears the loss for not doing so, that asset tends to deteriorate." But the theory long predates Rawls, and indeed a version appears in Blackstone:

As human life also grew more and more refined, abundance of conveniences were devised to render it more easy, commodious, and agreeable; as, habitations for shelter and safety, and raiment for warmth and decency. But no man would be at the trouble to provide either, so long as he had only an usufructuary property in them, which was to cease the instant that he quitted possession.

2 William Blackstone, Commentaries 4 ( 1766 ). Again:

It was clear that the earth would not produce her fruits in sufficient quantities, without the assistance of tillage: but who would be at the pains of tilling it, if another might watch an opportunity to seise [sic] upon and enjoy the product of his industry, art, and labor? Had not therefore a separate property in lands, as well as moveables, been vested in some individuals, the world must have continued a forest, and men have been mere animals of prey ....

ld. at 7 . This is an essentially economic theory of property rights, derived from the basic economic insight that rational actors will not invest effort in maintaining a good without an adequate incentive to do so, which a property interest in the good provides.

94. See Phillips, 524 U.S. at 165.

95. For this reason, a superficially plausible alternative to IOLTA-nanely, presenting clients with a inenu of possible charities to which they can direct their interest, rather than sending it all to low-income legal services-would in reality be tantamount to ensuring that none of the charities 
the spite right in the interest has been taken, and spite has no market value. Only blocking the transfer to IOLTA can make good the lost spite rightbut the Takings Clause permits property owners to obtain compensation, not to block takings. When the only just compensation is blocking the taking, constitutional takings jurisprudence collapses. The fault is really the Supreme Court's decision in Phillips. Bad law makes hard cases.

Hard cases or not, however, Phillips forced lower courts to confront the takings issue. The proper approach is to deny that a spite right, unsupported by any other rights in the property-rights bundle, deserves constitutional protection, because the Takings Clause is not designed to protect it. The Takings Clause balances public needs against private, by permitting private property to be taken for a public purpose but then compensating the owner. To permit owners to prevent takings would destroy this balance, sacrificing public needs to private desires. By stipulating financial compensation as the constitutionally mandated remedy for a taking, the Takings Clause presupposes that the harm the owner suffers is his economic loss, not his inability to veto the public purpose for which his property is being used. ${ }^{96}$ If in fact all that matters to aggrieved owners is

receives anything. Additionally, the interest is tax-exempt only if the clients who own it have no control over how it is disposed, and that is another reason that the menu-of-charities possibility would simply dissipate the interest rather than benefiting the charities. Phillips, 524 U.S. at 162 (citing Rev. Rul. 81209, 1981-2 C.B. 16; Rev. Rul. 87-2, 1987-1 C.B. 18). Finally, it seems doubtful that state supreme courts have the authority to raise money for purposes unrelated to the administration of justice, whereas providing legal scrvices for indigcnts falls comfortably within the sphere of authority of the courts, just as courts traditionally have the power to appoint counsel for indigent litigants. On the nature of the courts' inherent powers, see generally Charles W. Wolfram, MODERN Legal Ethics 2.2, at 22-23 (1986) (analyzing the inherent-powers doctrine in the rcgulation of lawyers); Charles W. Wolfram, Lawyer Turf and Lawyer Regulation-The Role of the Inherent-Powers Doctrine, 12 U. ARK. LITTLE Rock L. REv. 1 (1989-90) (same). At the December oral argument of Washington Legal Foundation v. Legal Foundation of Washington, Justice Breyer speculated that lOLTA plans do not violate the Takings Clause, but may violate the Due Process Clause of the Fifth and Fourteenth Amendments. However, precisely because enhancing the administration of justicc and regulating lawyer trust accounts fall within the traditional powers of state judiciaries, while altcrnative uses of the trustaccount money do not-and are practically infeasible-IOLTA plans secm plainly to serve a constitutionally legitimate regulatory purpose and do not violate the Due Process Clause.

96. However, vetoing the public purpose is precisely what the WLF seeks to do. WLF asks for an injunction to stop IOLTA programs, on the ground that just compensation for the lost intercst amounts to $100 \%$ of the interest, and under such circumstances it would bc absurd to pcrmit the taking in the first place. WLF Petitioncrs' Brief, supra note 90, at *16. But, even if the WLF succeeds in persuading the Court that IOLTA amounts to an unconstitutional taking, the proper remedy would be simple, and far less drastic than an injunction: any client who does not want his intercst to go to IOLTA's recipients can ask for it back-and receive a check for $\$ 0$, or possibly a bill, if the interest turns out to be less than the cost of processing it. This strikes me as poetic justice. All clients whose money will be kept by lawyers will be informed that they have a choice between letting the money be deposited in IOLTA accounts, or receiving a check for $\$ 0$ or possibly a bill. Presumably, those (and only those) who share the convictions of the WLF and its clients will be willing to pay to prevent their interest from going to low-income legal-services providers. My guess is that this will not make a sizeable dent in IOLTA. The injunctive remedy, by contrast seems genuinely outrageous, because it shuts down IOLTA programs on behalf of the small number of ideologues who hate legal-services lawyers. As Justice Ginsburg observed at the oral argumcnt, the only two possible recipients for uncollectible interest on 
vetoing the use of their assets for a public purpose, the presupposition underlying the Takings Clause fails, and the Takings Clause by its very terms cannot and should not give owners what they ask. This is precisely the situation in the IOLTA cases, where the plaintiffs' financial loss is notional not real, and their aim in filing suit is only to interfere with the public purpose of funding indigent legal services. The proper outcome of the cases is therefore to uphold IOLTA against the challengers.

\section{The First Amendment}

As mentioned above, the Ninth Circuit sitting en banc remanded Washington Legal Foundation to the district court to consider arguments that mandatory IOLTA contributions amount to compulsory speech and association, violating the First Amendment rights of protestors. ${ }^{97}$ Although the Supreme Court has sustained such challenges to mandatory labor-union dues $^{98}$ and mandatory bar-association dues, ${ }^{99}$ it has done so only when the unions or bar associations were spending the money on contentious political activities rather than on their core functions. ${ }^{100}$ Providing legal representation to underserved populations should be regarded as a core function of the judicial system, not a partisan political act, and so courts should reject the First Amendment challenge to judicially mandated IOLTA participation. $^{101}$

Clearly IOLTA challengers do not see it that way: to them, poor people's lawyers are political adversaries. In the words of a WLF press release, "the use of the plaintiffs' funds violates their First Amendment rights by forcing them to finance ideological causes with which they disagrce."102

client funds are IOLTA programs and banks, and the injunction would take away from all clients (not just those who object to IOLTA) the option of letting the money go to IOLTA programs. Apparently, the WLF would prefer that it all go to the banks.

97. See Wash. Lcgal Found. v. Legal Found. of Wash., 271 F.3d 835, 841 (9th Cir. 2001).

98. Abood v. Detroit Bd. of Educ., 431 U.S. 209 (1977) (holding that First Amendment prohibits labor unions from expending nonmembers' agency-shop fees on political activities).

99. Keller v. State Bar of Cal., 496 U.S. 1 (1990) (holding that First Amendment prohibits mandatory bar associations from requiring members to pay dues that are spent on political activities).

100. For a discussion and critique of the Court's reasoning in these eases, see David Luban, The Disengagement of the Legal Profession: Keller v. State Bar of California, 1990 SuP. Cr. Rev. 163, 177-88 (1991).

101. See Keller, 496 U.S. at 14 ("[T]he guiding standard must be whether the challenged expenditures are necessarily or reasonably ineurred for the purpose of ... "improving the quality of the legal scrvice available to the people of the State."') (quoting Lathrop v. Donahue, 367 U.S. 820,843 (1960)); Lathrop, 367 U.S. at 843 ("[1]mproving the quality of legal service available to the people of the State ... is a legitimate end of state policy."). Indeed, impecunious civil litigants can enjoy a constitutional right to counsel in cascs implicating important rights when the risk of error is high and the cost to government is not overwhelming. See Lassiter v. Dep't. of Soc. Servs., 452 U.S. 18 (1981).

102. Wash. Legal Found., Litigation Update: U.S. Appeals Court Hands WLF WASHINGTON STATE IOLTA ViCTORY (Jan. 10, 2001), available at hitp://www.wlf.org/ upload/1-10-01.pdf. The quoted statcment is difficult to reconcile with WLF's assertion in its Supreme Court brief that providing legal services is a "laudable publie goal." WLF Petitioncrs' Brief, supra note 90 , at *22. 
But the compulsory speech argument is extraordinary. Contributors know only th: IOLTA money goes to fund poor people's lawyers. They have no idea who the lawyers are, who their clients are (other than that they are poor), what issues the lawyers will argue, or what they will say. To assert that making them contribute IOLTA interest compels clients to fund speech that they abhor is tantamount to saying that they abhor anything that anyone might say on behalf of a poor person. It follows that what bothers the objectors is not the speech (about which they know nothing), but the speaker. Talk of compelled speech muddies the issue, which, if it is about anything, is about compelled association rather than compelled speech.

In reality, however, both arguments are overwrought. Funding speech, indirectly and at a distance, is not the same as speaking, nor is it the same as associating with the speaker, except in a figurative and highly attenuated way. The arguments rest on little more than a metaphor. Proponents of such arguments sometimes quote Thomas Jefferson's maxim "To compel a man to furnish funds for the propagation of ideas he disbelieves and abhors is sinful and tyrannical." 103 But the ordinary business of government and commerce seldom takes this overblown rhetoric seriously. For example, federal tax dollars pay the salaries of senators whose words many constituents find hateful. Atheists fund plenty of God-talk by government officials, creationists subsidize federally funded research on evolutionary biology, and we all pay the salaries of public prosecutors and defenders who say things that occasionally make us seethe. For that matter, it seems likely that virtually every consumer purchase helps pay for corporate speech that the same consumers disagree with (and please do not reply that making purchases is optional rather than compelled behavior). All these examples of so-called compelled speech and association are in reality nothing more than necessary incidents to living in society, where (in Hampshire's words ${ }^{104}$ ) conflict is unavoidable and desirable. The multitude of clients whose uncollectible interest goes to IOLTA are in the same boat as taxpayers and consumers: they are thinly and anonymously connected to any particular expenditure of their money. In 2001 for example, the Texas IOLTA program generated about $\$ 5.6$ million from a million discrete deposits. ${ }^{105}$ Nothing ties any individual depositor tightly enough to any individual argument by a legal-service lawyer to make the claims of compelled

103. Thomas Jefferson, An Act for Establishing Religious Freedom, in The Life and Selected Writings of Thomas JefFerson 312 (Koch \& Peden eds., 1972). The Court quotes this passage in several eases. See e.g., Abood, 431 U.S. at 234-35 n.31; Int'l. Assoc. of Maehinists v. Street, 367 U.S. 740,770 (1960) (another union-dues case).

104. HAMPSHIRE, supra note 11 , at 37.

105. See Brief of Amici Curiae for Forty-Nine State Bar Associations and the National Association of IOLTA Programs, 2001 U.S. BRIEFS 1325, at *10 (Lexis 2002), Wash. Legal Found. v. Legal Found. of Wash., 122 S. Ct. 2355 (2002) (No. 01-1325). 
"speech" and compelled "association" any more than hyperbole and metaphor.

It is not just the arguments in the IOLTA litigation that are extraordinary, however. The litigation presents the spectacle of a comfortably funded public-interest law firm-the WLF, which has an annual budget of $\$ 4$ million, $32 \%$ of which comes from corporate contributions ${ }^{106}$ - trying to defund other public-interest lawyers because they have different politics. As the next Part will illustrate, such attacks on indigent lawyers by wellfunded groups are not limited to attacks against IOLTA.

\section{Law School Clinics and the Battle of New Orleans}

Today, 182 American law schools offer clinics in more than I30 different subject areas, staffed by more than 1,400 clinical instructors. Counting salaries, fringe benefits, and overhead, law schools annually invest perhaps $\$ 280$ million in clinical education. ${ }^{107}$ In return, clinics provide millions of hours each year of unpaid student legal work. ${ }^{108}$

It should be noted that very little clinical work is "cause" lawyering, that is, lawyering "directed at altering some aspect of the social, economic, and political status quo." 109 Civil and criminal litigation clinics form the backbone of clinical education in the United States, and they typically provide one-client-at-a-time, more-or-lcss routine, direct client representation. Clinical education also includes street-law programs, entrepreneurial clinics with business clients, and externships. ${ }^{110}$ It seems likely, however, that

106. The WLF has an annual budget of $\$ 4$ million, comprised of corporate contributions (32\%), foundation grants (45\%), and investments (8\%). See Washington Legal Foundation, How to Support the WLF, at http://www.wlf.org/resources/wlfmission/support.asp (last visited Oct. 8, 2002).

107. The median and mean salary for full-time clinical teachers is approximately $\$ 88,000$ per year, which works out to $\$ 123.2$ million in clinician salaries. Assuming $25 \%$ of salary for benefits, and $100 \%$ for overhead, the total investment comes to $\$ 280$ million. Information about the number of clinics and clinicians, and clinical salaries, comes courtesy of David Chavkin, who maintains a database for the Clinical Legal Education Association ("CLEA"). See Email from David Chavkin to the author (Aug. 29,2001 ) (on file with the author).

108. There are no exact figures to tally the hours. However, a calculation based on the following assumptions shows that as many as three million hours of clinical work are provided each year: (1) that $90 \%$ of the 1,400 clinicians are teaching in any given semester; (2) that three-quarters of those clinicians are in fact teaching clinic rather than classroom; (3) that each clinical teacher supervises eight students; (4) that the early weeks of an assumed fifteen-week semester are occupied with training rather than client representation, and that the work tapers off at the end of the semester, so that students represent clients for ten weeks in a semester; (5) that clinical work averages twenty hours per week per student. These assumptions (which are no better than educated guesses), imply 7,500 clinical students per semester, each contributing 200 hours of indigent representation, for a total of 1.5 million hours, or three million hours in an academic year.

109. Austin Sarat \& Stuart Scheingold, Cause Lawyering and the Reproduction of Professional Authority: An Introduction, in Cause Lawyering: Political Commitments and Professional ResponsibILITIES 4 (Austin Sarat \& Stuart Scheingold eds., 1998).

110. These are among the clinical programs listed by CLEA. See Michigan Law School Clinical Law Programs, Gateway to Clinical Legal Education, at http://cgi2.www.law.umich.edu/_GCLE/ index.asp (last visited Oct. 8, 2002). 
the overwhelming majority of clinical teachers would identify themselves as political progressives. ${ }^{111}$ While nothing in principle prevents conservatives from starting clinics devoted to issues they favor, for example, crime victims' rights or small business deregulation clinics, it has rarely come to pass, although the WLF started an Economic Freedom Law Clinic at George Mason Law School, which takes a "pro-free enterprise, limited government, and economic freedom perspective."112 The perception of a leftward tilt makes law school clinics a natural target for adversaries of progressive public-interest law. Although relatively infrequently, law school clinics have indeed been subjected to political attacks and silencing doctrines.

The principal lightning rod has been environmental-law clinics, which sometimes take anti-development stances that put them at odds with business interests. In the 1980 s, under pressure from the timber industry, the University of Oregon School of Law's environmental-law clinic came under siege, and eventually had to leave the law school. ${ }^{113}$ Environmental-law clinics in the University of West Virginia College of Law and University of Wyoming College of Law have also been attacked by politicians and business interests. ${ }^{114}$ Most recently, the University of Pittsburgh School of Law's environmental law clinic infuriated the state legislature by filing suits delaying highway and logging projects in a national forest. ${ }^{115}$ The Pittsburgh Post-Gazette reported that under pressure from the legislature, the University of Pittsburgh law school took back $\$ 60,000$ of the clinic's $\$ 100,000$ annual budget, a move denounced by the university faculty's Tenure and Academic Freedom Committee as a violation of academic freedom. ${ }^{116}$

The most notorious effort to silence an environmental-law clinic involves Tulane Law School, a private law school in New Orleans. After the Tulane environmental clinic successfully stopped a polyvinylchloride factory from locating in a low-income Black residential neighborhood, angry

111. This, at any rate, is my perception based on years of involvement with clinical education.

112. Washington Legal Foundation, Economic Freedom Law Clinic at the George Mason University School of Law, at http://www.wlf.org/Litigating/econfreedom.asp (last visited Oct. 8, 2002).

113. See Peter A. Joy \& Charles D. Weisselberg, Access to Justice, Academic Freedom, and Political Interference: A Clinical Program Under Siege, 4 Clinical L. REV. 531, 533 (1998).

114. Robert R. Kuehn, Denying Access to Legal Representation: The Attack on the Tulane Environmental Law Clinic, 4 WASH. U. J.L. \& POL'Y. 33, 103 (2000).

115. See Johnna A. Pro, Road Group Targets Law Clinic at Pitt, Pittsburgh Post-GazetTe, Aug. 24, 2001, at B-4; Senator Wants to Punish Pitt for Logging Suit, PA. L. WeEKLy, May 28, 2001, at 9 .

116. See Don Hopey, Law Clinic at Pitt Feeling Pressure; Controversy Swirls Over Environmental Clients, Pittsburgh Post-Gazette, Oct. 17, 2001, at B-1; Don Hopey \& Bill Shackner, Faculty Rips Pitt, Defends Law Clinic, Pittsburgh Post-Gazette, Jan. 29, 2001. 
business groups complained to the Louisiana Supreme Court. ${ }^{17}$ In response, the court amended its student-practice rule, Rule XX, to make it harder for students to represent environmental groups. ${ }^{118}$

Clinic supporters filed a federal law suit on academic freedom and free speech grounds. ${ }^{119}$ The WLF and, ironically, the Economic Freedom Law Clinic at George Mason Law School weighed in on the opposite side with an amicus brief. Subsequently, the WLF also placed an anticlinic attack ad in the New York Times, explaining why it opposes law school clinics. ${ }^{120}$ The advertisement assails law school clinics for "suing property owners, representing criminals, filing appeals on behalf of convicted murderers, and tormenting small business with novel theories of legal liability." 21 At one point the ad poses a question: "Why do law schools fear a level playing field?"122 This question is striking coming from an organization campaigning for a playing field with no opponent.

Currently, the anti-environmental-clinic rule, Rule XX, stands. The district court sided with the Louisiana Supreme Court and the Fifth Circuit Court of Appeals affirmed. ${ }^{123}$ The heart of the Fifth Circuit's argument is that the Louisiana Supreme Court has no obligation to permit unlicensed

117. See Peter A. Joy, Political Interference with Clinical Legal Education: Denying Access to Justice, 74 TUlaNe L. REv. 235 (1999); Kuehn, supra note 114; see also Joy \& Weisselberg, supra note 113 .

118. In brief, the rule tightened eligibility requirements so that law school clinics may represent only low-income organizations (at least $51 \%$ of the members of any organization a Louisiana clinic represents must qualify individually for student representation) and may not solicit clients. See LA. State SuP. CT. R. XX § 5 (200I) (limiting student representation of organizations to those in which $51 \%$ of members are eligible for student representation); id. $\S 10$ (prohibiting clinicians from soliciting cases or clients). The former requirement means that low-income clients will lose their lawyers as soon as they begin to associate with those who possess greater resources. Nor does association with those who possess greater resources mean that groups will be able to retain private counsel, obviating the need for student representation. A citizens' coalition of poor people and their lower-middle-class neighbors will seldom be able to afford private eounsel for a lengthy, complex environmental case seeking political or equitable relief rather than damages. In any event, private environmental lawyers are often conflicted out of pro bono cases because their paying elients will be damaged by proenvironmentalist decisions.

119. S. Christian Leadership Conference, La. Chapter v. Sup. Ct. of La., 61 F. Supp. 2d 499 (E.D. La. 1999).

120. See Daniel J. Popeo, A One-Sided Paper Chase, advertisement, N.Y. Times, Feb. 20, 2000, at A23. Mr. Popeo, the Chairman of the WLF, sneers at "Ameriea's brightest law students grappl[ing] with such important concerns as whether plants, bacteria, monkeys, snails, or owls have legal rights," and he eharges that legal clinics are "stuck in a time warp" of "I960s activism." Id. According to the advertisement, clinies are headquarters of hostility to free enterprise, they agitate, they intimidate conservative students, they encourage radical causes, they bias nonclinical as well as clinical students against business, they engage in exotic activities, and they lack academic integrity. Clinical education provides "few opportunities to represent crime victims and small business owners who eannot afford lawyers;" instead, it exposes students to "a heavy dose of ideological activism." Id.

121. Id.

122. Id.

123. See S. Christian Leadership Conference, La. Chapter v. Sup. Ct. of La., 252 F.3d 781 (5th Cir. 2001); S. Christian Leadership Conference, La. Chapter v. Sup. Ct. of La., 61 F. Supp. 2d 499 (E.D. La. 1999). 
law students to represent any clients at all. ${ }^{124}$ That means its new studentpractice rule cannot violate the clinician's rights because they have no such rights. ${ }^{125}$ The court adds that it does not matter whether the Louisiana Supreme Court was responding to pressure from groups whose motivation was political and retaliatory. There is no viewpoint discrimination because Rule XX does not prevent anyone from speaking, it merely refuses to promote certain kinds of speech. It is "suppressive' only in comparison to the earlier version of Rule XX."126 The court explained that, since the Louisiana court was under no obligation to permit any student to practice law, Rule XX suppressed no right because there was no baseline right to suppress. In effect, the Fifth Circuit told the clinic students that they should be grateful that the Louisiana justices let them into court at all. ${ }^{127}$

This argument about baselines is willfully blind to the real baselinethe reality created by custom and history. Law school clinics are not simply a sop thrown to law students, an incidental afterthought in the legal landscape. For thirty years clinics have been an accepted, routinc part of that landscape. They are valued everywhere for the services they provide and the training they offer; and it would be difficult to deny that providing legal services and teaching lawyers their craft are central goals of legal institutions. This thirty-year history should set the baseline, not the court's formal power to eliminate clinics by decree.

The Fifth Circuit writes as though permitting students to represent clients is an act of grace by the Louisiana justices, because it is an exception to the rule that only lawyers can practice law. But this argument gets matters completely upside down. In most walks of life, it is restrictions on the market for services that call for a special justification and open access that is the preferred rule. To my knowledge, only two arguments are ever offered to justify the state-sanctioned professional monopoly: restricting the practice of law to trained, barred lawyers is supposed to protect consumers from incompetent representation and unethical representation. ${ }^{128}$

However, no one was complaining about the competence or the ethics of the student lawyers at Tulane or any other Louisiana law school. The complaint was that they represented the wrong causes. ${ }^{129}$ The state supreme

124. See S. Christian Leadership Conference, 252 F.3d at 794-95.

125. Id.

126. Id. at 795 (emphasis in original).

127. "[T]he LSC [Louisiana Supreme Court] need not have allowed any unlicensed student to serve in an attorney representative capacity. The Court has chosen to allow the unlicensed student clinic members to engage in the practice of law in Louisiana under certain conditions." Id. at 794.

128. For an official statement of the arguments for restricting the practice of law to licensed lawyers, see MODEl CODE of Prof'L Responsibility EC 3-1-3-4 (1983).

129. See Resolution of the Louisiana Supreme Court Upon Amending Rule XX, reprinted in 74 TuL. L. REv. 285, 297 (1999) (Johnson, J., dissenting):

This court received complaints from the Chamber of Commerce/New Orleans and the River Region and from the Business Council of New Orleans and the River Region.... and a 
court had been lobbied by three powerful business associations to clamp down on the law students. ${ }^{130}$ The justices were up for re-election. ${ }^{131}$ The federal district judge thought this was irrelevant: dismissing the clinicians' lawsuit, he wrote, "in Louisiana, where state judges are elected, one cannot claim complete surprise when political pressure somehow manifests itself within the judiciary." 132 No doubt; but such complacent cynicism seems wholly out of place in a legal opinion about whether a politically motivated rule is viewpoint discrimination. Of course it is viewpoint discrimination, as Justice Johnson makes clear: the Louisiana Supreme Court was muscled to stop environmental challenges to business. ${ }^{133}$

The attacks on the environmental-law clinics at the University of Pittsburgh and Tulane failed to shut them down, I am happy to report. Facing criticism from the Association of American Law Schools and the American Association of University Professors, in March, 2002, the University of Pittsburgh School of Law's dean reversed his decision to assess the clinic its $\$ 60,000$ overhead costs. ${ }^{134}$ And, according to Tulane clinic's director Adam Babich, Rule XX has not prevented the clinic from continuing its work. ${ }^{135}$ That is not the point, however. If the attacks failed, they were near misses, and eventually some will succeed. Indeed, they may already have succeeded in one of their aims, because clinic directors will undoubtedly hesitate before taking on volatile cases that may provoke dangerous backlash against the clinics or their law schools. Obviously, the degree to which clinicians self-censor cannot be known, but everyone in clinical education with whom I have discussed the subject agrees that selfcensorship exists. In effect, thc assaults on environmental-law clinics function like SLAPP suits, intimidating law school administrators and clinic directors even when they fail.

complaint from the Louisiana Association of Business and Industry.... The complaints suggested that the environmental law student practitioners should be regulated more closely because business in the state was being negatively impacted by their misguided challenges to environmental permits and other practices.

Id.

130. Id.

131. See S. Christian Leadership Conference, La. Chapter v. Sup. Ct. of La., 61 F. Supp. 2d 499, 513 (E.D. La. 1999).

132. Id.

133. See supra note 129.

134. Terry Carter, Law Clinics Face Critics: Business Interests Fire Up Challenges to Schools' Environmental Law Projects, 88 A.B.A.J. 24 (July 2002).

135. Megan Kamerick, Hostile Environment: Tulane Law Clinic Continues Work Despite Limitations on Student Attorneys, New ORLeans City Business (Nov. 18, 2002), at 10A; see also adam Babich, How the Tulane Environmental law Clinic Survived the Shintech CONTROVERSY AND RULE XX: SOME QUESTIONS AND ANSWERs, available at http://www.tulane.edu/ -telc/Life\%20with\%20Rule\%XX.pdf. 


\section{The Civil Rights Fee Cases}

In more than half a dozen decisions over the past fifteen years, the U.S. Supreme Court has cut back on statutorily authorized attorneys' fees given to prevailing parties in civil rights and environmental cases. ${ }^{136} \mathrm{Be}$ cause they create weapons that adversaries can use to attack the funding of civil rights and environmental lawyers, at least two of these decisions create silencing doctrines.

The first is the Court's I986 decision Evans v. Jeff D. ${ }^{137}$ Here, a civil rights defendant offered a settlement granting the plaintiff full relief, provided that the plaintiff waived statutory attorneys' fees. Legal-aid lawyers represented the plaintiff. ${ }^{138}$ Counsel concluded that they had no ethical alternative to accepting the offer, but later moved to have the fee-waiver set aside because the defendant had exploited their ethical obligation and undercut Congress's intention in enacting the fee-award statute. ${ }^{139}$ The Court, through Justice Stevens, disagreed. The Court admitted that a "sacrifice offer" (that is, "tell your client that we will give her everything she wants provided that you do not get paid") creates an instant tension between attorney and client; ${ }^{140}$ the client wins only if the attorney loses. However the Court denied that this raises any genuine problem of legal ethics, because plaintiff's counsel can always fulfill their ethical obligations by sacrificing their statutorily authorized fees. ${ }^{141}$ The Court acknowlcdged but dismissed

136. These statutory-fees cases include:

(1) Marek v. Chesny, 473 U.S. 1 (1985). The fee-shifting statute here is the Civil Rights Attorneys' Fees Awards Act of 1976, 42 U.S.C. $§ 1988$. Here the Court (per Chief Justice Burger) held that if a plaintiff prcvails at trial but wins less than a settlement offer, the plaintiff cannot rccover attorneys' fees. Marek has the effect of making it risky to go to trial in an undeveloped area of the law or with an unsympathetic plaintiff, even if a settlement offer is unpleasantly low.

(2) City of Burlington v. Dague, 502 U.S. 1071 (1992). The fee-shifting statutes here are contained in the Solid Waste Disposal Act, 42 U.S.C. $\S 6972(\mathrm{e})$, and the Clean Watcr Act, 33 U.S.C. $\S$ 1365(d). Courts sometimes cnhance statutory attorney's fees through a "risk multiplier" designed to compensate the attorney for accepting a risky case. Here the Court (per Justice Scalia) sharply limited the discretion of trial judges to award risk multipliers to victorious civil rights attorneys. $I d$.

(3) Memphis Cmty. Sch. Dist. v. Stachura, 477 U.S. 299 (1986); Carey v. Piphus, 435 U.S. 247 (1978). These decisions, both authored by Justice Powell, limit damages in civil rights cases to contexts of actual damage, rather than merely dignitary injury. Although statutory attorney's fees need not be proportional to damages, settlements often allocate attorney's fees as a function of compensation, and so the net effect is to diminish attorney's fees.

(4) Farrar v. Hobby, 506 U.S. 103 (1992). Although the attorney's fee statute makes fees available to the "prevailing" party, the Court, per Justice Thomas, held that a plaintiff winning only nominal damages need not be entitled to attorney's fees. (The Court pared back an even more aggressive Fifth Circuit opinion, however, which held that a plaintiff winning only nominal damages is not a prevailing party.) Id.

137. 475 U.S. 717 (1986).

138. Id. at 721 .

139. Id. at 723 .

140. Id. at 727 .

141. Id. at 727-28. 
the possibility that the widespread practice of skillfully targeted sacrifice offers could put a public-interest firm out of business. ${ }^{142}$

In practice, private civil rights lawyers have avoided the problem of sacrifice offers by writing retainer agreements that make clients responsible for the attorney's fees if they accept a sacrifice offer. ${ }^{143}$ But as Justice Brennan noted in his dissent in Jeff $D$., public-interest lawyers who write such retainer agreements risk their tax-exempt status. ${ }^{144}$ Additionally, even private practitioners report that the Court's Jeff $D$. decision has eut back their ability to negotiate good settlements for their clients by requiring them to negotiate the merits and the fees separately. ${ }^{145}$

The Court's reasoning in Jeff $D$. is hard to fathom. It says that having to choose between your client's interests and your own livelihood creates no ethical dilemmas, because you can always sacrifice yourself on the altar of duty. But on this planet, conflicts of interest are ethical dilemmas. While the written codes of ethics provide no express prohibition on lawyers representing clients whose cases would threaten the lawyer's financial interests, they rightly single these cases out as problem situations that deserve special scrutiny. ${ }^{146}$

In his dissent in Jeff $D$., Justice Brennan urged state bars to enact an ethics rule prohibiting defense lawyers from making sacrifice offers, and I have heard public-interest lawyers agree that this is the solution. ${ }^{147}$ However, this approach is unworkable. A legal-ethics rule cannot prohibit defendant clients from proposing a sacrifice settlement, and it should not prohibit their lawyers from presenting to the adversary the settlement their clients propose. Otherwise, clients will simply communicate with their adversaries directly. Nor can the rule forbid defense lawyers from counseling

142. Id. at $741 \mathrm{n} .34$. The Court's reason for dismissing the possibility is that no evidence exists that sacrifice offers seriously threaten the civil rights plaintiffs' bar, and thus it would be premature to interpret the statute with that possibility in mind. Id. Justice Brennan's dissent properly excoriates this argument. He argues that it is mere common sense that the prospect of investing months or years in a case in which an attorney might be compelled to sacrifice all fees would discourage attorneys from taking cases; no scientific study is necessary to prove that. He further points out that the Court's majority is itself perfectly willing to substitute common-sense predictions for scientific studies when it argues that permitting sacrifice offers will facilitate the settlement process. Id. at 754-58 (Brennan J. dissenting).

143. See Julie Davies, Federal Civil Rights Practice in the 1990's: The Dichotomy Between Reality and Theory, 48 Hastings L.J. 197 (1997). In this valuable study, Davies interviewed thirty-five civil rights practitioners to learn how their practices were affected by the string of Supreme Court decisions. She discovered that their effects on private practitioners were indirect, consisting largely of a shifting of bargaining power in settlement to their adversaries. Id.

144. See Jeff D., 475 U.S. at 757 n.10 (Brennan, J., dissenting).

145. See Davies, supra note 143.

146. See Model Rules of Prof'L Conduct R. 1.7(b) (2002) (“A lawyer shall not represent a client if the representation of that client may be materially limited ... by the lawyer's own interests, unless (1) the lawyer reasonably believes the representation will not be adversely affected; and (2) the client consents after consultation.").

147. See Jeff D., 475 U.S. at 765. 
their clients to make the sacrifice offer, as that would be a gross interference with the lawyer's right to say what she wishes to her client. Perhaps other rules could be amended to permit public-interest lawyers to write fee agreements making their clients responsible for their fees if they accept a sacrifice offer. But public-interest lawyers might still be very reluctant to write such agreements, because given their clients' straitened finances, the agreement will inevitably seem exploitative and extortionate. Most likely, the only resolution to the silencing doctrines espoused in Jeff $D$. must come from Congress or the Supreme Court.

In addition to Jeff D., the Court recently decided Buckhannon v. West Virginia Department of Health and Human Services. ${ }^{148}$ The Buckhannon Court held, in a five-to-four decision, that if a defendant gives a plaintiff the sought-after relief before there has been a judicial decision or a judicially approved settlement, then the plaintiff does not count as a prevailing party and receives no statutory attorneys' fees. ${ }^{149}$ This eliminates a socalled catalyst theory used by many courts, according to which plaintiffs were awarded attorney's fees if it was determined that their litigation efforts were the catalyst bringing about the relief or settlement, so that they deserve the fees that go to prevailing parties. ${ }^{150}$ After Buckhannon, a vindictive defendant can throw in the towel on the eve of judgment to stop the onset of fee shifting, after the plaintiff and plaintiff's counsel have accrued years of expenses. Buckhannon thus creates another silencing doctrine by discouraging plaintiffs lawyers from litigating expensive suits that previously held the allure of recouping costs through fee shifting.

The Court's opinion (written by Chief Justice Rehnquist) offers no satisfactory explanation for the decision. It does little more than review past decisions on the meaning of the term "prevailing party" and then refuse to extend the word "prevailing" to include a party gaining what it wants from its lawsuit without judicial involvement. ${ }^{151}$ But why not extend the word that far? If getting what one wants through an approved settlement counts as "prevailing," why should not gaining the identical relief through the identical lawsuit still count as "prevailing" even if there is no official settlement? The Court does not say, but Justice Scalia's concurrence tries to answer these questions. He argues that without some judicial involvement, there is no way of knowing whether the plaintiff's case was

148. 532 U.S. $598(2001)$. The fee-shifting statutes here are contained in the Fair Housing Amendments Act, 42 U.S.C. $\S 3613$ (c)(2), and the Americans with Disabilities Act, 42 U.S.C. $\$ 12205$. Although the WLF did not participate in this case, the Pacific Legal Foundation, another conservative public-interest law firm, filed an amicus brief on behalf of the respondent.

149. Buckhannon, 532 U.S. at 600 .

150. Id. at 601-02.

151. Id. at 603-04 (reviewing past decisions on the meaning of "prevailing party"); id. at 605 ("We think, however, the "catalyst theory' falls on the other side of the line from these examples."). 
"phony." 152 Maybe the plaintiff's lawyer is an "extortionist" who made the defendant cry uncle merely by manipulating the media, or by running up defendant's legal bills. ${ }^{153}$ ("Phony" and "extortionist" are Justice Scalia's words, not mine.)

However, high-profile media cases are rare; cases where the plaintiff rather than the defendant runs the adversary's legal-fee meter are rarer still. Why build a rule around rare exceptions? Why not presume that, if the defense capitulates, it is probably because the plaintiff had a credible ease? Justice Scalia's hypotheticals seem to rest on little more than a visceral suspicion of plaintiffs' lawyers. In any event, his argument fails because judicial involvement provides no remedy to the evils he fears. Judges never disapprove settlements merely because the defendant settled to avoid bad publicity or attorney's fees. Judges think these are splendid reasons to settle. ${ }^{154}$ Therefore, cases where the defendant surrenders for these reasons are no different than cases where the defendant settles, except that in the latter the law grants statutory attorneys' fees.

One prominent public-interest lawyer described the effects of Buckhannon:

Oy. Don't get me started. The only word is "disastrous." There is now the lethal combination of Jeff D. and Buckhannon. Jeff D. was bad, and like everyone else we've suffered through more than our share of sacrifice offers. But Buckhannon's significance can't be overstated. True example: We've been litigating fiercely a longstanding dispute with an agency. We have just received a letter-after years of litigation mind you-saying, in essence, "you're right, we're wrong, we will change our policy to address your concerns." No judicial order will or now can be entered because the case will be moot. ... I have no hope of getting fees here post-Buckhannon, though we have, even using [the statute's] low rates, probably $\$ 40,000$ in fees in the case. That is a big chunk of my budget. We see this kind of pattern: lengthy litigation, and at some point, capitulation, time and again. Up until now, using a catalyst theory, we could often get fees in these cases (although at

152. Id. at 617 (Scalia, J. concurring).

153. Id. at 618 .

154. Federal Rule of Civil Procedure 16 tells judges that it is appropriate to use pretrial conferences to facilitate settlements, and the Civil Justice Reform Act of 1990, 28 U.S.C. $\$ \$ 471-482$, whieh aims at the reduction of costs and delays in civil litigation, has led the judiciary to favor a policy of settling cases whenever possible. See FED. R. CIv. P. 16. Marc Galanter has thoroughly explored the great value the judiciary places on securing settlements. See, e.g., Marc Galanter \& Mia Cahill, "Most Cases Settle": Judicial Promotion and Regulation of Settlements, 46 STAN. L. REv. 1339 (1994); Marc Galantcr, The Emergence of the Judge as a Mediator in Civil Cases, 69 JuDiCature 256, 257-62 (1986) (discussing the history of the judicial role in settlement); Marc Galanter, ". . A Settlement Judge, not a Trial Judge:" Judicial Mediation in the United States, 12 J.L. \& Soc'y 1, 4-8 (1985). 
times we've encountered the Jeff D./sacrifice offer problem). Now we have no chance. I can't tell you how dispiriting this is for us. ${ }^{155}$

\section{CONCLUSION}

Silencing doctrines raise the prospect of an adversary system in which one set of adversaries, the progressive public-interest lawyers and the clients they represent, is relentlessly squeezed by political opponents who would rather muzzle them than argue against them. Those who value procedural justice should find silencing doctrines deeply offensive.

The argument of this Essay is not that lack of lawyers is the greatest evil a low-income person can face, nor do I suggest that legal injustice is worse than injustice in other forms and forums. We should not forget the well-known, sardonic responses "let them eat due process"156 and "the rich get richer and the poor get lawyers."157 These responses remind us that America's thirty million poor people have long lists of needs, and legal representation may be far down the list. But that misses the point. Even if silencing doctrines are not among life's gravest injustices, they represent an outrageous violation of what the legal system should be.

This response might be thought naïve. Public-interest law has long been an active front in the larger culture wars that mark American politics. Surely no one should be shocked, shocked to learn that politics is going on here. But I am not shocked; I am merely disgusted. I believe that fairminded individuals, regardless of their political orientation, should accept the principle of adversary argument, audi alteram partem. When politics impinges on the imperative to hear both sides, the adversary system threatens to dissolve into farce or fraud. As Hampshire has argued, even those engaged in political hardball should hear the other side. Otherwise, political hardball slides inexorably into mere brutality. ${ }^{158}$

Political attacks require political responses. Obviously, the injustice of silencing doctrines is unlikely to become an electoral issue-the issues are too specialized and too remote. They are issues for the bar, not the voters, to take up. However, this is unlikely to happen so long as the bar perceives nothing more than partisan squabbles between the Left and the Right over

155. Email from David Vladeck, Publie Citizen Litigation Group, to the author (June 27, 2001) (on file with the author). Buckhannon may not be the last word on Supreme Court silencing doctrines. The Court has agreed to hear arguments in a case challenging contingency fees in social security cases; the Bush administration contends that lawyers representing social security claimants should be compensated according to the lodestar (hourly) formula, which does not pay as well. The WLF has filed an amicus brief on behalf of the administration's position. See Marcia Coyle, High Court to Hear Social Security Case Fee Controversy, NAT'L. L.J., Mar. 11, 2002, at A15.

156. Craig Haney, The Fourteenth Amendment and Symbolic Legality: Let Them Eat Due Process, 15 LAW \& HUM. BeHAv. 183 (1991).

157. Stephen Chapman, The Rich Get Rich, and the Poor Get Lawyers, New Republic, Sept. 24, 1977 , at 9.

158. See HAMPSHIRE, supra note 14 , at 186-87. 
relatively esoteric matters (the legal-services restrictions, IOLTA, environmental-law clinics, fee-shifting rules). The point of this Essay is that these issues are not discrete; they form a dangerous pattern. More importantly, combating silencing doctrines is not a partisan issue involving only the lawyers the doctrines harm. It is an issue for every lawyer who supports the minimum procedural justice embodied in the injunction to hear both sides. It is important for lawyers and bar groups to speak out against the legal-services restrictions, to maintain IOLTA accounts even if the Supreme Court strikes down mandatory IOLTA programs, to support embattled environmental-law clinics, and to work to enact legislation to reverse Buckhannon. These should be regarded as matters of fundamental procedural justice, not partisan politics.

Let me add one final thought. The private demon of all progressive public-interest lawyers is a sense of futility. Few lawyers who win so few cases and lose so many are immune from the gnawing sense that they are merely wasting their time. It sometimes seems as though their voices accomplish little beyond making a historical record of rejected arguments on behalf of vanquished causes. But they do win sometimes, and even when they fail, the alternative is not making a historical record, so that the very fact that they had a cause disappears without a trace. Without their voices, a kind of smug consensus - a lie, really-is the outcome. And the adversary system becomes little more than a field of lies. Even enemies of progressive public-interest lawyers should want something more than this. 